\section{Nauplius}

The Journal OF The

Brazilian Crustacean Society

e-ISSN 2358-2936

www.scielo.br/nau www.crustacea.org.br

\title{
Catalogue of terrestrial isopods (Crustacea, Isopoda, Oniscidea) from Brazil: an update with some considerations
}

\author{
Ivanklin Soares Campos-Filho' ${ }^{1}$ iD orcid.org/0000-0001-6139-8241 \\ Giovanna Monticelli Cardoso² (iD orcid.org/0000-0003-2682-1643 \\ José Otávio Aguiar ${ }^{1}$ (D) orcid.org/0000-0003-0489-3670
}
1 Universidade Federal de Campina Grande, Programa de Pós-Graduação em Recursos Naturais. Av. Aprígio Veloso, 882, Bairro Universitário. 58429-140 Campina Grande, Paraíba, Brazil.
ISC-F E-mail: ivanklin.filho@gmail.com
JOA E-mail: otavio.j.aguiar@gmail.com
2 Universidade Federal do Rio Grande do Sul, Programa de Pós-Graduação em Biologia Animal, Departamento de Zoologia, Laboratório de Carcinologia. Av. Bento Gonçalves, 9500, Agronomia. 91510-979 Porto Alegre, Rio Grande do Sul, Brazil. GMC E-mail: jojomonticelli@hotmail.com

ZOOBANK: http://zoobank.org/ urn:lsid:zoobank.org:pub:B6FA42D7-5B80-4921B174-F1B6E7768EB5

\section{ABstract}

All species of Brazilian terrestrial isopod known up to date, including references and distribution information, are listed. The list comprises 189 valid species, 135 of which are endemic to the country, 22 are recorded also from other countries in the Americas, 20 are introduced, and 12 have circumtropical or pantropical distributions.

\section{KEY WORDS}

Distribution, faunistics, Neotropical Region, species list, taxonomy.

\section{INTRODUCTION}

Terrestrial isopods (Oniscidea) constitute one of the most remarkable

CORRESPONDING AUTHOR Ivanklin Soares Campos-Filho ivanklin.filho@gmail.com

SUBMITTED 06 December 2017 ACCEPTED 27 July 2018 PUBLISHED 06 December 2018

DOI 10.1590/2358-2936e2018038

\section{$(\mathrm{cc}) \mathrm{BY}$}

All content of the journal, except where identified, is licensed under a Creative Commons attribution-type BY.

Nauplius, 26: e2018038 
the terrestrial isopods from the New World, recorded approximately 110 species and two unnamed species in Brazil, one in the genus Ethelum Budde-Lund, 1899 and the other in the genus Periscyphis Gerstaecker, 1873. Schmalfuss (2003) recognized approximately 120 valid species from Brazil.

In the last years, many studies increased the knowledge about the terrestrial isopods biodiversity in Brazil (e.g., Schmidt and Leistikow, 2005; Souza et al., 2011; Campos-Filho et al., 2015a; 2015b; 2014; 2017a; 2017c; Souza et al., 2015; Cardoso et al., 2016; Grangeiro et al., 2017). Although some of these studies provided an estimation of about 170 species in Brazil (Campos-Filho et al., 2017b; 2017c), none of them offered a real number of valid species.

This study lists all terrestrial isopods species from Brazil until September, 2018, providing an update to the catalogues published by Souza-Kury (1998), Leistikow and Wägele (1999), and Schmalfuss (2003). In addition, information on bibliography and species distributions is given, as well as remarks whenever necessary.

\section{Material and Methods}

This study is based on an extensive bibliographical survey on the terrestrial isopod diversity in Brazil. The synonymic list includes original descriptions and publications mentioning species occurring in Brazil. Also included are some testimonial specimens of a few species deposited in the Coleção de Crustáceos do Departamento de Zoologia, Universidade Federal do Rio Grande do Sul (UFRGS).

Brazil has 26 states plus a Federal District (Distrito Federal) distributed in 5 regions: Northern (states of Rondônia, Acre, Amazonas, Roraima, Pará, Amapá, and Tocantins), Northeastern (states of Alagoas, Bahia, Ceará, Maranhão, Paraíba, Pernambuco, Piauí, Rio Grande do Norte, and Sergipe), Southeastern (states of Espírito Santo, Minas Gerais, Rio de Janeiro, and São Paulo), Southern (states of Paraná, Rio Grande do Sul, and Santa Catarina), and CenterWestern (states of Goiás, Mato Grosso, Mato Grosso do Sul, and Distrito Federal).

\section{Systematic Account}

\section{Family Ligiidae Leach, 1814}

\section{Genus Ligia Fabricius, 1798}

\section{Ligia baudiniana Milne-Edwards, 1840}

Ligia baudiniana Milne-Edwards, 1840: 155-156.

Lygida baudiniana - Moreira, 1931: 433.

Ligia (Hirtiligia) baudiniana - Van Name, 1936: 58,

fig. 14. - Vandel, 1952a: 80.

Ligia baudiniana - Andersson, 1960a: 540. - Souza-

Kury, 1998: 657. - Leistikow and Wägele, 1999:

2. - Schmalfuss, 2003: 124.

Distribution. Atlantic and Pacific American coasts, from Florida to Brazil and from California to Ecuador, including the Galapagos Islands (Schmalfuss, 2003; López-Orozco et al., 2014). In Brazil, it is recorded from the states of Paraíba, Pernambuco and Rio de Janeiro (Souza-Kury, 1998).

\section{Ligia exotica Roux, 1828}

Ligia exotica Roux, 1828: 3, pl. XIII, fig. 9. Andersson, 1960a: 540, fig. 1k-1. - Lemos de Castro, 1971: 9, fig. 4. - Souza, 1998: 101. - Souza-Kury, 1998: 657. - Leistikow and Wägele, 1999: 2. - Schmalfuss, 2003: 124. - Lopes et al., 2006: 5, figs. 2-15. - LopesLeitzke et al., 2009: 735, figs. 1-7. - Lopes-Leitzke, 2011: 149, figs. 1-8.

Ligyda exotica - Richardson, 1905: 676, figs. 716, 717. - Van Name, 1920: 72, figs. 27-30. - Moreira, 1931: 433.

Ligyda olfersii - Richardson, 1905: 674, figs. 714, 715. - Van Name, 1920: 77, figs. 31-34. - Moreira, 1931: 433.

Ligia (Megaligia) olfersii - Van Name, 1936: 53, figs. 5d, 11.

Ligia olfersii - Souza-Kury, 1998: 657. - Schmalfuss, 2003: 127.

Distribution. Circumtropical species (Schmalfuss, 2003). Specimens of L. exotica deposited in the UFRGS collection were sampled in Salvador, state of Bahia 
(9ત, 5, UFRGS 4697); Bombinhas, state of Santa Catarina $(7 \hat{\sigma}, 5$, UFRGS 4696); and Torres, state of Rio Grande do Sul (3ત̄, 10 , UFRGS 2499). To date, this species is recorded from the states of Bahia, Rio de Janeiro, Santa Catarina and Rio Grande do Sul (Richardson, 1905; Andersson, 1960a; Lopes et al., 2006; Lopes-Leitzke et al., 2009; 2011).

\section{Family Tylidae Milne-Edwards, 1840}

\section{Genus Tylos Audouin, 1826}

\section{Tylos niveus Budde-Lund, 1885}

Tylos niveus Budde-Lund, 1885: 274. - Lemos de Castro, 1971: 9, fig. 15. - Souza-Kury, 1998: 668. Leistikow and Wägele, 1999: 4. - Schmalfuss, 2003: 282. - Silva and Alves, 2000: 268, figs. 1-23.

Tylos latreillii niveus - Lemos de Castro, 1952: 2, figs. 1-13.

Distribution. Tylos niveus is recorded from the coasts of Florida (USA), Bahamas, Belize, Bermudas, Colombia, Costa Rica, Cuba and other Caribbean Islands, Ecuador, Mexico, Venezuela, and Puerto Rico (Schmalfuss, 2003; Jass and Klausmeier, 2006; Hurtado et al., 2014; Carpio-Díaz et al., 2016; Taiti et al., 2018). In Brazil, it is considered an introduced species and recorded from the states of Rio de Janeiro and Santa Catarina (Lemos de Castro, 1952; Leistikow and Wägele, 1999; Silva and Alves, 2000; Schmalfuss, 2003).

\section{Family Trichoniscidae Sars, 1899}

\section{Genus Haplophthalmus Schöbl, 1860}

\section{Haplophthalmus danicus Budde-Lund, 1880}

Haplophthalmus danicus Budde-Lund, 1880: 9. - Lemos de Castro, 1971: 3, fig. 2. - Souza-Kury, 1998: 668 Araujo and Bueno, 1998: 185. - Araujo, 1999a: 247, fig. 12. - Leistikow and Wägele, 1999: 6. - Schmalfuss, 2003: 104.

Distribution. European species introduced to many parts of the world (Vandel, 1963; Schmalfuss, 2003). In Brazil, the species is recorded from the states of Rio
Grande do Sul and São Paulo (Lemos de Castro, 1971; Araujo and Bueno, 1998).

\section{Genus Miktoniscus Kesselyák, 1930}

\section{Miktoniscus medcofi (Van Name, 1940)}

Trichoniscus (Miktoniscus) medcofi Van Name, 1940: 109, fig. 2.

Miktoniscus medcofi - Lemos de Castro, 1953: 529, fig. I. - Lemos de Castro, 1971: 10, fig. 3. - Souza-Kury, 1998: 668. - Araujo and Bueno, 1998: 186. - Araujo, 1999a: 241, fig. 11. - Leistikow and Wägele, 1999: 7. - Schmalfuss, 2003: 166. - Campos-Filho et al., 2014: 363, figs. 1-4. - Campos-Filho et al., 2015a: 117. - Campos-Filho et al., 2017c: 2.

Distribution. Miktoniscus medcofi is recorded from Brazil, Mexico and southern and central USA (Schmalfuss, 2003). In Brazil, it is considered an introduced species, recorded from the states of Pará, Paraná and Rio Grande do Sul (Araujo and Bueno, 1998; Campos-Filho et al., 2014; 2015a; 2017c).

\section{Family Styloniscidae Vandel, 1952}

\section{Genus Clavigeroniscus Arcangeli, 1930}

\section{Clavigeroniscus riquieri (Arcangeli, 1930)}

Trichoniscus riquieri Arcangeli, 1930: 25, fig. VIII, 1-14.

Clavigeroniscus riquieri - Lemos de Castro, 1967: 314. - Souza-Kury, 1998: 667. - Leistikow and Wägele, 1999: 9. - Schmalfuss, 2003: 72.

Distribution. Pantropical species (Schmalfuss, 2003). In Brazil, it is recorded from the states of Amapá and Pará (Lemos de Castro, 1967).

\section{Genus Cordioniscus Gräeve, 1914}

\section{Cordioniscus stebbingi (Patience, 1907)}

Trichoniscus stebbingi Patience, 1907: 42, pl. VIII.

Cordioniscus stebbingi - Lemos de Castro, 1953: 533, Estampa II. - Lemos de Castro, 1971: 2. - SouzaKury, 1998: 667. - Leistikow and Wägele, 1999: 9. - Schmalfuss, 2003: 74.

Distribution. Synanthropic species introduced to many parts of the world (Schmalfuss, 2003). In Brazil, 
it is recorded from the states of Rio de Janeiro and São Paulo (Lemos de Castro, 1953; 1971).

\section{Genus Cylindroniscus Arcangeli, 1929}

\section{Cylindroniscus flaviae Campos-Filho, Araujo and Taiti, 2017}

Cylindroniscus flavie Campos-Filho, Araujo and Taiti, in Campos-Filho et al., 2017a: 229, figs. 1A, C, 2-5. Campos-Filho et al., 2017b: 70. - Silva et al., 2018: 56.

Distribution. Troglophile and endemic species recorded from several caves in the Açungui karst area, state of São Paulo (Campos-Filho et al., 2017a).

\section{Cylindroniscus platoi Fernandes, Campos- Filho and Bichuette, 2018}

Cylindroniscus platoi Fernandes, Campos-Filho and Bichuette, 2018: 413, figs 1-6.

Distribution. Troglobitic and endemic species recorded from the Pedro Leopoldo karst area, state of Minas Gerais (Fernandes et al., 2018).

\section{Genus Iuiuniscus Souza, Ferreira and Senna, 2015}

\section{Iuiuniscus iuiuensis Souza, Ferreira and Senna, 2015}

Iuiuniscus iuiuensis Souza, Ferreira and Senna, 2015: 6, figs. 1-3, 4D, E, 5, 6. - Campos-Filho et al., 2016: 2. - Angarten et al., 2017: 17. - Bastos-Pereira et al., 2017: 292. - Campos-Filho et al., 2017b: 70. - Cavalcanti, 2017: 50, Tab. 2. - Gallão and Bichuette, 2018: 7, Tab. 1. - Silva et al., 2018: 55.

Distribution. Troglobitic and amphibious species endemic to Lapa do Baixão cave, Iuiú, state of Bahia (Souza et al., 2015).

\section{Genus Pectenoniscus Andersson, 1960}

\section{Pectenoniscus angulatus Andersson, 1960}

Pectenoniscus angulatus Andersson, 1960a: 550, figs. 6, 7. - Bastos-Pereira et al., 2017: 292.
Distribution. Endogean species endemic to Nova Teutonia, state of Santa Catarina (Andersson, 1960a).

\section{Genus Spelunconiscus Campos-Filho, Araujo and Taiti, 2014}

\section{Spelunconiscus castroi Campos-Filho, Araujo and Taiti, 2014}

Spelunconiscus castroi Campos-Filho, Araujo and Taiti, in Campos-Filho et al., 2014: 368, figs. 5-8, 40. - Campos-Filho et al., 2016: 2. - Angarten et al., 2017: 17. - Bastos-Pereira et al., 2017: 292. - Campos-Filho et al., 2017b: 70. - Cavalcanti, 2017: 50, Tab. 2. - Gallão and Bichuette, 2018: 7, Tab. 1. - Silva et al., 2018: 56.

Distribution. Troglobitic and amphibious species endemic to Gruta MOC-32 cave, Matozinhos, state of Minas Gerais (Campos-Filho et al., 2014).

\section{Genus Styloniscus Dana, 1852}

\section{Styloniscus sp. (cf. S. otakensis sensu Vandel, 1952 nec Chilton, 1901)}

Styloniscus otakensis - Lopes et al., 2005: 101, Tab. 1. - Zimmermann et al., 2015a: 3, Tab. 1.

Remarks. Chilton (1901) described Trichoniscus otakensis from South Island, New Zealand. The author mentioned that the buccal pieces, male pereopods and pleopods 1 and 2 were similar to T. phormianus [= Styloniscus p. (Chilton, 1901)] and did not describe them. Vandel (1952b), based on material from Omaio, east coast of North Island, New Zealand, placed the species in the genus Styloniscus and provided the description and illustrations of the sexual characters of the male, i.e., the pereopod 7 ischium distally enlarged, pleopod 1 exopod triangular and pleopod 2 endopod very long with tapering distal portion. Green (1971) revised Chilton's type material and in the illustration of the male pereopod 7 ischium the enlargement figured by Vandel is not present, the male pleopod 1 exopod is concave on outer distal portion and the male pleopod 2 endopod is stout and slightly cleft at apex. However, Green considered Vandel's specimens as a variation within the species. Comparing the descriptions provided 
by the authors, it is clear that the specimens examined by Vandel (1952b) correspond to a different species from that described by Chilton (1901). Recently, the same morphological characteristics described by Vandel (1952b) were observed in specimens collected from Brazil (Lopes et al. 2005; Zimmermann et al. 2015a; present material). However, it is not certain that the Brazilian specimens are identical to those from New Zealand described by Vandel and a comparison with those specimens is necessary. Certainly, they do not belong to S. otakensis (Chilton, 1901).

Distribution. Recorded from the Parque Estadual do Monge, state of Paraná, and São Francisco de Paula, state of Rio Grande do Sul (Zimmermann et al., 2015a). Specimens deposited at UFRGS were sampled from Parque Estadual do Monge, state of Paraná $(1 \hat{\jmath}, 1$ 우, 3 juveniles, UFRGS 6544).

\section{Styloniscus spinosus (Patience, 1907)}

Trichoniscus spinosus Patience, 1907: 85, pl. III.

Styloniscus spinosus - Magrini et al., 2010: 216. Magrini et al., 2011: 65. - Campos-Filho et al.,2017c: 2.

Distribution. This species is recorded from greenhouses in Great Britain, Hawaii (USA), Madagascar, Mauritius and Réunion (Schmalfuss, 2003). In Brazil, it is considered introduced and recorded from the states of Paraná, São Paulo and Santa Catarina (Magrini et al., 2010; 2011; CamposFilho et al., 2017c).

\section{Genus Xangoniscus Campos-Filho, Araujo and Taiti, 2014}

\section{Xangoniscus aganju Campos-Filho, Araujo and Taiti, 2014}

Thailandoniscus sp. 2 - Trajano and Bichuette, 2010: 10, Tab. 1. - Cavalcanti, 2017: 50, Tab. 2.

Xangoniscus aganju Campos-Filho, Araujo and Taiti, in Campos-Filho et al., 2014: 373, figs. 9-13, 40. Campos-Filho et al., 2016: 2. - Campos-Filho et al., 2017b: 70. - Fernandes et al., 2016: 7, Tab. 1. - Trajano et al., 2016: 1817. - Angarten et al., 2017: 17. - BastosPereira et al., 2017: 292. - Cavalcanti, 2017: 50, Tab.
2. - Gallão and Bichuette, 2018: 7, Tab. 1. - Silva et al., 2018: 56.

Distribution. Troglobitic and amphibious species endemic to Gruna do Mandiaçu cave, Cariranha, state of Bahia (Campos-Filho et al., 2014).

\section{Xangoniscus itacarambiensis Bastos-Pereira, Souza and Ferreira, 2017}

Xangoniscus itacarambiensis Bastos-Pereira, Souza and Ferreira, 2017: 292, figs. 1D-5. - Campos-Filho et al., 2017b: 70. - Gallão and Bichuette, 2018: 7, Tab. 1. - Silva et al., 2018: 56, Tabs. 1-4, figs. 2c, 3-9, 10a-d, f.

Distribution. Troglobitic and amphibious species endemic to Olhos D'Água cave, Itacarambi, state of Minas Gerais (Bastos-Pereira et al., 2017).

\section{Xangoniscus odara Campos-Filho, Bichuette and Taiti, 2016}

Xangoniscus odara Campos-Filho, Bichuette and Taiti, 2016: 2, figs. 2-7, 14. - Angarten et al., 2017: 17. - Campos-Filho et al., 2017b: 70. - Bastos-Pereira et al., 2017: 292. - Gallão and Bichuette, 2018: 7, Tab. 1. - Silva et al., 2018: 56.

Distribution. Troglobitic and amphibious species endemic to Lapa do Cipó cave, Itacarambi, state of Minas Gerais (Campos-Filho et al., 2016).

\section{Family Olibrinidae Budde-Lund, 1913}

\section{Genus Olibrinus Budde-Lund, 1913}

\section{Olibrinus antennatus (Budde-Lund, 1902)}

Trichoniscus antennatus Budde-Lund, 1902: 379. Olibrinus antennatus - Araujo and Taiti, 2007: 347, figs. $1,2$.

? Olibrinus sp. - Lemos de Castro, 1972a: 357. Taiti and Ferrara, 2004: 227.

Distribution. Amphibious species common to mangroves and under coral rocks along the coasts 
of the tropics (Araujo and Taiti, 2007). In Brazil, it is recorded from Rocas Atoll, state of Rio Grande do Norte (Araujo and Taiti, 2007).

Family Alloniscidae Schimdt, 2003

\section{Genus Alloniscus Dana, 1854}

\section{Alloniscus buckupi Campos-Filho and Cardoso, 2018}

Alloniscus buckupi Campos-Filho and Cardoso, in Campos-Filho et al., 2018a: 2, figs. 1-4.

Distribution. Supralitoral and endemic to Brazil (state of Paraíba) (Campos-Filho et al., 2018a).

\section{Family Philosciidae Kinahan, 1857}

\section{Genus Alboscia Schultz, 1995}

\section{Alboscia itapuensis Araujo and Quadros, 2005}

Alboscia itapuensis Araujo and Quadros, 2005: 56, figs. 1-20.

Distribution. Endogean species endemic to Brazil (state of Rio Grande do Sul) (Araujo and Quadros, 2005).

\section{Alboscia ornata Araujo, 1999}

Alboscia ornata Araujo, 1999b: 491, figs. 17-31. Schmalfuss, 2003: 10.

Distribution. Endogean species endemic to Brazil (state of Rio Grande do Sul) (Araujo, 1999b).

\section{Alboscia silveirensis Araujo, 1999}

Alboscia silveirensis Araujo, 1999b: 489, figs. 1-16. Lopes et al., 2005: 101, Tab. 1. - Schmalfuss, 2003: 10.

Distribution. Endogean species endemic to Brazil (state of Rio Grande do Sul) (Araujo, 1999b; Lopes et al., 2005).

\section{Genus Androdeloscia Leistikow, 1999}

\section{Androdeloscia albamaculata (Lima, 1996)}

Prosekia albamaculata Lima, 1996a: 102, figs. 1-17. - Souza-Kury, 1998: 661. - Leistikow and Wägele, 1999: 22.

Prosekia albomaculata [sic] - Schmalfuss, 2003:216.

Androdeloscia albamaculata - Leistikow, 2001a: 112. - Leistikow, 2001b: 6, Tab. 1. - López-Orozco et al., 2016: 19.

Distribution. Endemic to Brazil (Marchantaria Island, state of Amazonas) (Lima, 1996a).

\section{Androdeloscia digitata Leistikow, 1999}

Androdeloscia digitata Leistikow, 1999: 836, figs. 60-63, 65. - Leistikow, 2001b: 6, Tab. 1. - Schmalfuss, 2003: 18. - Schmidt and Leistikow, 2005: 127, fig 37. - Grangeiro and Christoffersen, 2010: 79. - LópezOrozco et al., 2016: 25.

Distribution. Endemic to Northern Brazil (state of Amazonas) (Leistikow, 1999).

\section{Androdeloscia escalonai Schmidt and Leistikow, 2005}

Androdeloscia escalonai Schmidt and Leistikow, 2005: 128, figs. 9-15. - Grangeiro et al., 2017: 375, fig. 7.

Distribution. This species was originally described from Cueva del Viento, Falcón, Venezuela (Schmidt and Leistikow, 2005). In Brazil, it is recorded from Reserva Florestal Adolpho Ducke, Itacoatiara, state of Amazonas (Grangeiro et al., 2017).

\section{Androdeloscia leilae Grangeiro and Christoffersen, 2010}

Androdeloscia leilae Grangeiro and Christoffersen, 2010: 80, figs. $1-5$. 
Distribution. Endemic to Northern Brazil (Januari Lake and Tarumã Mirim River, Amazon Forest, state of Amazonas) (Grangeiro and Christoffersen, 2010).

\section{Androdeloscia lejeunei (Lemos de Castro and Souza, 1986)}

Prosekia lejeunei Lemos de Castro and Souza, 1986: 432, figs. 13-26. - Souza-Kury, 1998: 662. - Leistikow and Wägele, 1999: 22. - Schmalfuss, 2003: 216.

Androdeloscia lejeunei - Leistikow, 2001a: 112. Leistikow, 2001b: 6, Tab. 1. - López-Orozco et al., 2016: 19. - Campos-Filho et al., 2017c: 2.

Distribution. Endemic to Brazil (state of Pará) (Lemos de Castro and Souza, 1986; Campos-Filho et al., 2017).

\section{Androdeloscia silvatica (Lemos de Castro and Souza, 1986)}

Prosekia silvatica Lemos de Castro and Souza, 1986: 432, figs. 1-12. - Souza-Kury, 1998: 662. - Leistikow and Wägele, 1999: 22.

Androdeloscia silvatica - Leistikow, 1999: 838. Leistikow, 2001a: 112. - Leistikow, 2001b: 6, Tab. 1. - Schmalfuss, 2003: 18. - Schmidt and Leistikow, 2005: 117, figs. 5, 6, 37. - Souza and Grangeiro, 2006: 35, figs. 1, 2, 4. - Grangeiro and Christoffersen, 2010: 80. - López-Orozco et al., 2016: 21.

Distribution. Endemic to the Brazilian and Venezuelan Amazon (Schmidt, 2007). In Brazil, this species is recorded from the states of Amazonas and Ceará (Lemos de Castro and Souza, 1986; Souza and Grangeiro, 2006). The state of Ceará is inserted into the Chacoan subregion (sensu Morrone 2014), and the Caatinga is the most expressive biome of the state (Oliveira et al., 2012). However, A. silvatica was recorded from a 'brejo' forest in the Araripe Plateou (Souza and Grangeiro, 2006), a historical bridge between the Amazon and Atlantic forests (Costa, 2003). According to Souza and Grangeiro (2006), this species represents a relict of an ancient connection between the Amazon and Atlantic forests, when the central portion of Brazil was covered by rain forests due to the moister conditions (see also Costa, 2003; Ledo and Colli, 2017).

\section{Androdeloscia tarumae (Lemos de Castro, 1984)}

Prosekia tarumae Lemos de Castro, 1984a: 442, figs. 1, 2. - Warburg et al., 1997: 52, figs. 1, 2. - SouzaKury, 1998: 662. - Leistikow and Wägele, 1999: 22. - Schmalfuss, 2003: 217.

Androdeloscia tarumae - Leistikow, 1999: 839. Leistikow, 2001a: 112. - Leistikow, 2001b: 6, Tab. 1. - Schmidt and Leistikow, 2005: 127. - Grangeiro and Christoffersen, 2010: 80. - López-Orozco et al., 2016: 19.

Distribution. Endemic to Northern Brazil (Tarumã Mirim River, Manaus, state of Amazonas) (Lemos de Castro, 1984a).

\section{Genus Atlantoscia Ferrara and Taiti, 1981}

\section{Atlantoscia antennamaculata Campos-Filho, Cardoso and Araujo, 2018}

Atlantoscia antennamaculata Campos-Filho, Cardoso and Araujo, in Zimmermann et al., 2018b: 553, figs. 1-3, 7, 8, Tabs. 1, 2.

Distribution. Endemic to Brazil (state of Santa Catarina) (Zimmermann et al., 2018b).

\section{Atlantoscia australis Campos-Filho, Cardoso and Araujo, 2018}

Atlantoscia australis Campos-Filho, Cardoso and Araujo, in Zimmermann et al., 2018b: 555, figs. 4-6, 7, 8, Tabs. 1, 2.

Distribution. Endemic to Brazil (state of Santa Catarina) (Zimmermann et al., 2018b).

\section{Atlantoscia floridana (Van Name, 1940)}

Philoscia floridana Van Name, 1940: 113, fig. 4.

Chaetophiloscia paulensis - Vandel, 1963: 74, figs. 7, 8. - Lemos de Castro, 1971: 11. - Lemos de Castro, 1972a: 357.

Chaetophiloscia sp. - Vandel, 1963: 76.

Atlantoscia alceui - Ferrara and Taiti, 1981: 190, figs. 1-4. - Lemos de Castro, 1985a: 418, figs. 1-16. 
Atlantoscia floridana - Taiti and Ferrara, 1991: 902, figs. 1-15. - Araujo et al., 1996: 115, figs. 11-14 and 64. - Souza-Kury, 1998: 658. - Araujo, 1999a: 249, fig. 16. - Araujo and Leistikow, 1999: 117, figs. 6-10. - Leistikow and Wägele, 1999: 13. - Leistikow, 2001b: 6. - Leistikow and Araujo, 2001: 330, fig. 1, pl. 1a, b. - Schmalfuss, 2003: 49. - Araujo and Bond-Buckup, 2004: 1, figs. 2-6, Tabs. 1-3. - Araujo and Bond-Buckup, 2005: 290, figs. 3-11, Tabs. 1-5. - Araujo et al., 2004a: 952, figs. 1-46, Tabs. 1, 2. - Araujo et al., 2004b: 222, figs. 2-30, Tabs. 1-3. - Lopes et al., 2005: 101, Tab. 1. Almerão et al., 2006: 474, fig. 4. - Quadros and Araujo, 2007: 242, figs. 1-3, Tabs. 1, 2. - Quadros and Araujo, 2008: 59, figs. 1, 2, Tabs. 1-5. - Quadros et al., 2009: 244, figs. 1, 3, Tabs. 1, 2. - Quadros, 2010: 573, fig. 1. Campos-Filho et al., 2012: 141. - Zimmermann et al., 2012: 712, fig. 1, Tab. 1. - Campos-Filho et al., 2013b: 464, fig. 12a. - Zimmermann et al., 2015a: 3, fig. 2, Tabs. 1, 2. - Zimmermann et al., 2015b: 702, figs. 5, 6, Tabs. 1-3. - Campos-Filho et al., 2017c: 5. - Wood et al., 2017: 4, figs. 4-7. - Zimmermann et al., 2018a: 474, Tabs. 1, 2, figs. 5, 6. - Zimmermann et al., 2018c, figs. 1-4.

nec Philoscia paulensis - Moreira, 1927: 194, figs. 1-3. - Moreira, 1931: 426, fig. 1. - Lemos de Castro, 1958a: 7. - Lemos de Castro, 1976: 391.

Distribution. Atlantoscia floridana was originally described from Florida, USA (Van Name, 1940) and recorded from Argentina, Brazil, coastal regions of Florida, and Ascension and St. Helena Island (Schmalfuss, 2003; Campos-Filho et al., 2013b). In Brazil, it is widely distributed from Amapá to Rio Grande do Sul states (Campos-Filho et al., 2013b; 2017c).

\section{Atlantoscia inflata Campos-Filho and Araujo, 2015}

Atlantoscia inflata Campos Filho and Araujo, in Zimmermann et al., 2015b: 705, figs. 1, 2, 5, 6, Tabs. 1-3. - Zimmermann et al., 2018a: 475, Tabs. 1, 2, figs. 5, 6. - Zimmernamm et al. 2018c, figs. 1-4.

Distribution. Endemic to Brazil (state of Rio Grande do Sul) (Zimmermann et al., 2015b).

\section{Atlantoscia meloi Campos-Filho and Araujo, 2015}

Atlantoscia meloi Campos Filho and Araujo, in Zimmermann et al., 2015b: 708, figs. 3-6, Tabs. 1-3. - Zimmermann et al., 2018a: 475, Tabs. 1, 2, figs. 5, 6.

Distribution. Endemic to Brazil (state of Santa Catarina) (Zimmermann et al., 2015b).

\section{Atlantoscia petronioi Campos-Filho, Contreira and Lopes-Leitzke, 2012}

Atlantoscia petronioi Campos-Filho, Contreira and Lopes-Leitzke, 2012: 138, figs. 1-5. - Campos-Filho et al., 2013b: 466, fig. 12b. - Zimmermann et al., 2015a: 3, fig. 2, Tabs. 1, 2. - Zimmermann et al., 2015b: 704, figs. 5, 6, Tabs. 1-3.-Zimmermann et al., 2018a: 475, Tabs. 1, 2, figs. 5, 6. - Zimmernamm et al. 2018c, figs. 1-4.

Distribution. Endemic to Brazil (state of Rio Grande do Sul) (Campos-Filho et al., 2012; Zimmermann et al., 2015a, 2015b).

\section{Atlantoscia sulcata Campos-Filho, Lisboa and Araujo, 2013}

Atlantoscia sulcata Campos-Filho, Lisboa and Araujo, 2013b: 472, figs. 6-12. - Zimmermann et al., 2015b: 704, figs. 5, 6, Tabs. 1-3. - Zimmermann et al., 2018a: 475, Tabs. 1, 2, fig. 5.

Distribution. Endemic to Brazil (state of São Paulo) (Campos-Filho et al., 2013b).

\section{Genus Benthana Budde-Lund, 1908}

\section{Benthana aimores Campos-Filho, Taiti and Araujo, 2015}

Benthana aimores Campos-Filho, Taiti and Araujo, 2015b: 56, figs. 35, 36, 43.

Distribution. Endemic to Brazil (state of Espírito Santo) (Campos-Filho et al., 2015b). 


\section{Benthana albomarginata Lemos de Castro, 1958}

Benthana albomarginata Lemos de Castro, 1958b: 95, figs. 16-20. - Boyko, 1997: 6. - Souza-Kury, 1998: 658. - Leistikow and Wägele, 1999: 13. - Schmalfuss, 2003 : 53. - Campos-Filho et al., 2015b: 23, figs. 12, 13, 16C.

Distribution. Endemic to Brazil (states of Espírito Santo and São Paulo) (Campos-Filho et al., 2015b).

\section{Benthana araucariana Araujo and Lopes, 2003}

Benthana araucariana Araujo and Lopes, 2003: 2433, figs. 32-44, 47, 49. - Schmalfuss, 2003: 53. Lopes et al., 2005: 101, Tab. 1. - Campos-Filho et al., 2015b: 53, fig. 33C.

Distribution. Endemic to Brazil (state of Rio Grande do Sul) (Campos-Filho et al., 2015b).

\section{Benthana bocainensis Lemos de Castro, 1958}

Benthana bocainensis Lemos de Castro, 1958b: 113, figs. 87-92. - Souza-Kury, 1998: 558. - Leistikow and Wägele, 1999: 13. - Schmalfuss, 2003: 53. - CamposFilho et al., 2015b: 35, figs. 21, 22, $25 \mathrm{C}$.

Distribution. Endemic to Brazil (Serra da Bocaina, Lageado, state of São Paulo) (Campos-Filho et al., 2015b).

\section{Benthana cairensis Sokolowicz, Araujo and Boelter, 2008}

Benthana cairensis Sokolowicz, Araujo and Boelter, 2008: 315, figs. 1-28. - Costa et al., 2014: 173, fig. 3. - Campos-Filho et al., 2015b: 53, fig. 33D. Zimmermann et al., 2015a: 3, Tab. 1.

Distribution. Endemic to Brazil (states of São Paulo, Paraná, Santa Catarina and Rio Grande do Sul) (Campos-Filho et al., 2015b; Zimmermann et al., 2015a).

\section{Benthana canastraensis Campos-Filho, Taiti and Araujo, 2015}

Benthana canastraensis Campos-Filho, Taiti and Araujo, 2015b: 63, figs. 41-43.

Distribution. Endemic to Brazil (Casca d'Anta, Serra da Canastra, state of Minas Gerais) (Campos-Filho et al., 2015b).

\section{Benthana carijos Costa, Campos-Filho and Araujo, 2014}

Benthana carijos Costa, Campos-Filho and Araujo, 2014: 170, figs. 1-3. - Campos-Filho et al., 2015b: 54, fig. 34D.

Distribution. Endemic to Brazil (states of São Paulo and Santa Catarina) (Campos-Filho et al., 2015b).

\section{Benthana convexa Lemos de Castro, 1958}

Benthana convexa Lemos de Castro, 1958b: 93, figs. 10-15. - Lenko, 1971: 7. - Souza-Kury, 1998: 659. - Araujo and Leistikow, 1999: 23, figs. 17-22. Leistikow and Wägele, 1999: 13. - Leistikow, 2001b: 6, Tab. 1. - Schmalfuss, 2003: 53. - Campos-Filho et al., 2015b: 22, fig. 16B.

Distribution. Endemic to Brazil (states of Minas Gerais, Rio de Janeiro, São Paulo and Santa Catarina) (Campos-Filho et al., 2015b).

\section{Benthana dimorpha Lemos de Castro, 1985}

Benthana dimorpha Lemos de Castro, 1985b: 246, figs. 14-25. - Souza-Kury, 1998: 659. - Leistikow and Wägele, 1999: 14. - Schmalfuss, 2003: 53. - CamposFilho et al., 2015b: 44, figs. 28, 29, 32B.

Distribution. Endemic to Brazil (state of Espírito Santo) (Campos-Filho et al., 2015b).

\section{Benthana goitacas Campos-Filho, Taiti and Araujo, 2015}

Benthana goitacas Campos-Filho, Taiti and Araujo, 2015b: 56, figs. 37, 38, 43. 
Distribution. Endemic to Brazil (state of Espírito Santo) (Campos-Filho et al., 2015b).

\section{Benthana guayanas Campos-Filho, Costa and Araujo, 2013}

Benthana guayanas Campos-Filho, Costa and Araujo, 2013a: 8, figs. 6-8. - Campos-Filho et al., 2015a: 112. - Campos-Filho et al., 2015b: 54, fig. 34C.

Distribution. Endemic to Brazil (states of Rio de Janeiro and Paraná) (Campos-Filho et al., 2013a; 2015b).

\section{Benthana iporangensis Lima and Serejo, 1993}

Benthana iporangensis Lima and Serejo, 1993: 490, figs. 1-4. - Pinto-da-Rocha, 1995: 97. - SouzaKury, 1998: 659. - Leistikow and Wägele, 1999: 14. - Schmalfuss, 2003: 53. - Campos-Filho et al., 2015b: figs. 30, 31, 32C. - Pires et al., 2015: 69, Tab. 1. - Trajano et al., 2016: 1819. - Bastos-Pereira et al., 2017: 292. - Cavalcanti, 2017: 49, Tab. 2. - Gallão and Bichuette, 2018: 7, Tab. 1.

Distribution. Troglobitic and endemic species recorded from Iporanga karst region, state of São Paulo (Campos-Filho et al., 2014, 2015b).

\section{Benthana itaipuensis Campos-Filho and Araujo, 2011}

Benthana itaipuensis Campos-Filho and Araujo, 2011a: 39, figs. 1-5. - Campos-Filho et al., 2013a: 3, 13. - Campos-Filho et al., 2015a: 112. - Campos-Filho et al., 2015b: 54, fig. 34B. - Zimmermann et al., 2015a: 3, Tab. 1.

Distribution. Endemic to Brazil (Foz do Iguaçu, state of Paraná) (Campos-Filho and Araujo, 2011). This species was collected near the borders with Argentina and Paraguay (see Campos-Filho and Araujo, 2011a).

\section{Benthana longicaudata (Lemos de Castro, 1958)}

Benthanoscia longicaudata Lemos de Castro, 1958c: 2, figs. 1-14. - Boyko, 1997: 6. - Souza-Kury, 1998: 660. - Leistikow and Wägele, 1999: 15. - Schmalfuss, 2003: 54 .
Benthana longicaudata - Leistikow, 2001b: 6, Tab. 1. - Campos-Filho et al., 2015b: 37, figs. 23, 24, 25 D.

Benthana (Benthanoscia) longicaudata - Leistikow and Araujo, 2006: 250, figs. 6-8.

Distribution. Endemic to Brazil (states of Minas Gerais, Rio de Janeiro and São Paulo) (Campos-Filho et al., 2015b).

\section{Benthana longicornis Verhoeff, 1941}

Benthana longicornis Verhoeff, 1941a: 121, figs. 1-7. - Gruner, 1955: 446, figs. 10-13. - Lemos de Castro, 1958b: 115, figs. 93-98. - Andersson, 1960a: 557, fig. 10. - Andersson, 1960b: 415. - Araujo et al., 1996: 115, figs. 5-10. - Souza-Kury, 1998: 659. - Leistikow and Wägele, 1999: 14. - Schmalfuss, 2003: 53. - Costa et al., 2014: 173, fig. 3. - Campos-Filho et al., 2015b: 13, figs. 5, 6, 9C.

Distribution. Endemic to Brazil (Distrito Federal and states of Paraná, São Paulo and Santa Catarina) (Campos-Filho et al., 2015b).

\section{Benthana longipenis Lemos de Castro, 1958}

Benthana longipenis Lemos de Castro, 1958b: 109, figs. 69-77. - Souza-Kury, 1998: 659. - Leistikow and Wägele, 1999: 14. - Schmalfuss, 2003: 53. - CamposFilho et al., 2015b: 32, figs. 19, 20, 25B. - Campos-Filho et al., 2017c: 8 .

Distribution. Endemic to Brazil (states of Minas Gerais, Rio de Janeiro, Rio Grande do Sul, and São Paulo) (Campos-Filho et al., 2015b; 2017c).

\section{Benthana moreirai Lemos de Castro, 1985}

Benthana moreirai Lemos de Castro, 1985b: 241, figs. 1-13. - Souza-Kury, 1998: 659. - Leistikow and Wägele, 1999: 14. - Schmalfuss, 2003: 53. - Costa et al., 2014: 174, fig. 3. - Campos-Filho et al., 2015b: 41, figs. 26, 27, 32A.

Benthana (Benthanoscia) moreirai - Leistikow and Araujo, 2006: 254.

Distribution. Endemic to Brazil (states of São Paulo and Santa Catarina) (Campos-Filho et al., 2015b). 


\section{Benthana olfersii (Brandt, 1833)}

Philoscia olfersii Brandt, 1833: 183. - MilneEdwards, 1840: 164. - Stuxberg, 1875: 43. - BuddeLund, 1880: 2. - Budde-Lund, 1885: 212. - Kraepelin, 1901: 204. - Van Name, 1925: 465.

Oniscus nigrescens Dana, 1853: 728, pl. XLVIII, fig. 1a-c. - Stuxberg, 1875: 43.

Philoscia (Benthana) olfersii - Budde-Lund, 1908: 289. - Jackson, 1926: 193, pl. VI. - Van Name, 1936: 130, fig. 62.

Halophiloscia brasiliensis Moreira, 1931: 428, Estampa II. - Van Name, 1936: 515, fig. 317. - Lemos de Castro, 1962: 6. - Leistikow and Wägele, 1999: 14.

Benthana olfersii - Gruner, 1955: 444. - Lemos de Castro, 1958b: 98, figs. 28-35. - Lenko, 1971: 7. - Souza-Kury, 1998: 659. - Leistikow and Wägele, 1999: 14. - Schmalfuss, 2003: 53. - Campos-Filho et al., 2015b: 10, figs. 3, 4, 9B.

Benthana (Benthanoscia) olfersii - Sokolowicz et al., 2008: 315, fig. 27. - Campos-Filho and Araujo, 2011a: 41, fig. 6A.

nec Philoscia olfersii - Pearse, 1917: 7 (= Parischioscia omissa (Van Name, 1936)).

Distribution. Endemic to Brazil (states of Rio de Janeiro and São Paulo) (Campos-Filho et al., 2015b).

\section{Benthana picta (Brandt, 1833)}

Philoscia picta Brandt, 1833: 183. - Milne-Edwards, 1840: 165. - Stuxberg, 1875: 43. - Budde-Lund, 1880: 2. - Budde-Lund, 1885: 213. - Dollfus, 1897: 2. Kraepelin, 1901: 204.

Philoscia (Benthana) picta - Budde-Lund, 1908: 289, fig. 43, pl. 16. - Jackson, 1926: 193, figs. 133-136, pl. 7. - Van Name, 1936: 129, fig. 61.

Benthana picta - Gruner, 1955: 445, figs. 7-9. Lemos de Castro, 1958b: 111, figs. 78-86. - Andersson, 1960a: 559. - Vandel, 1963: 77. - Schultz, 1995: 389. - Lenko, 1971: 7. - Souza-Kury, 1998: 659. - Araujo et al., 1996: 113, figs. 1-4. - Araujo, 1999a: 248, fig. 14. - Leistikow and Wägele, 1999: 14. - Leistikow and Araujo, 2001: 340. - Araujo and Lopes, 2003: 2437. - Schmalfuss, 2003:53. - Lopes et al., 2005: 101, Tab. 1. - Costa et al., 2014: 174, fig. 3. - CamposFilho et al., 2015b: 6, figs. 1, 2, 9A. - Zimmermann et al., 2015a: 3, Tab. 1.
Benthana sp. - Zimmermann et al., 2015a: 3, Tab. 1. nec Philoscia picta - Camargo, 1954: 126. - Camargo, 1955: 5 (= Balloniscus sellowii (Brandt, 1833)).

nec Benthana picta - Giambiagi de Calabrese, 1931: $424(=?)$.

Distribution. Endemic to South America, recorded from Brazil and Paraguay (Schmalfuss, 2003). In Brazil, it is distributed along the Brazilian Atlantic Forest from Espírito Santo to Rio Grande do Sul states (CamposFilho et al., 2015b).

\section{Benthana santosi Lemos de Castro, 1958}

Benthana santosi Lemos de Castro, 1958b: 106, figs. 60-68. - Souza-Kury, 1998: 660. - Leistikow and Wägele, 1999: 14. - Schmalfuss, 2003: 54. - CamposFilho et al., 2015b: 28, figs. 17, 18, 25A.

Distribution. Endemic to Brazil (states of Minas Gerais, Rio de Janeiro, São Paulo, and Santa Catarina) (Campos-Filho et al., 2015b).

\section{Benthana schmalfussi Campos-Filho, Costa and Araujo, 2013}

Benthana schmalfussi Campos-Filho, Costa and Araujo, 2013a: 4, figs. 3-5. - Campos-Filho et al., 2015b: 54, fig. 34B.

Distribution. Endemic to Brazil (state of Rio de Janeiro) (Campos-Filho et al., 2015b).

\section{Benthana schubarti Lemos de Castro, 1958}

Benthana schubarti Lemos de Castro, 1958b: 91, figs. 1-9. - Souza-Kury, 1998: 660. - Schmalfuss, 2003: 54. - Campos-Filho et al., 2015b: 18, figs. 10, 11, 16A.

Distribution. Endemic to Brazil (states of Minas Gerais, Rio de Janeiro, and São Paulo) (Campos-Filho et al., 2015b).

\section{Benthana serrana Araujo and Lopes, 2003}

Benthana serrana Araujo and Lopes, 2003: 2426, figs. 2-16, 45. - Schmalfuss, 2003: 54. - Lopes et al., 
2005: 101, Tab. 1. - Costa et al., 2014: 174, fig. 3. Campos-Filho et al., 2015b: 51, fig. 33A.

Distribution. Endemic to Brazil (states of Minas Gerais, Rio de Janeiro, Rio Grande do Sul, and Santa Catarina) (Campos-Filho et al., 2015b).

\section{Benthana sulcata Gruner, 1955}

Benthana sulcata Gruner, 1955: 447, figs. 14-17. - Lemos de Castro, 1958b: 102, figs. 40-49. - SouzaKury, 1998: 660. - Leistikow and Wägele, 1999: 14 . - Leistikow, 2001b: 6, Tab. 1. - Schmalfuss, 2003: 54. - Campos-Filho et al., 2015b: 16, figs. 7, 8, 9D.

Benthana (Benthanoscia) sulcata - Leistikow and Araujo, 2006: 254.

Distribution. Endemic to Brazil (states of Paraná, Rio de Janeiro, and São Paulo) (Campos-Filho et al., 2015b).

\section{Benthana taeniata Araujo and Buckup, 1994}

Benthana taeniata Araujo and Buckup, 1994a: 269, figs. 1-13, 28. - Souza-Kury, 1998: 660. - Araujo, 1999a: 248, fig. 15. - Leistikow and Wägele, 1999: 14 . - Leistikow, 2001b: 6, Tab. 1. - Araujo and Lopes, 2003: 2438. - Schmalfuss, 2003: 54. - Leistikow and Araujo, 2006: 244, figs. 1-5. - Costa et al., 2014: 175, fig. 3. - Campos-Filho et al., 2015b: 49, fig. 32D. Zimmermann et al., 2015a: 3, Tabs. 1, 2. - Bueno et al., 2018: 5, Tab. 1. - Zimmermann et al., 2018a: 475, Tabs. 1, 2, fig. 6 .

? Benthana sp. 2 - Zimmermann et al., 2015a: 3, Tab. 1.

Distribution. Endemic species distributed along Brazilian Atlantic Forest areas from Distrito Federal, and states of Minas Gerais, Mato Grosso do Sul, Paraná, Rio de Janeiro, Rio Grande do Sul, São Paulo, and Santa Catarina (Campos-Filho et al., 2015b).

\section{Benthana trinodulata Araujo and Lopes, 2003}

Benthana trinodulata Araujo and Lopes, 2003: 2430, figs. 17-31, 46, 48. - Schmalfuss, 2003: 54. - Lopes et al., 2005: 101, Tab. 1. - Campos-Filho et al., 2015b: 53, fig. 33B.
Distribution. Endemic to Brazil (state of Rio Grande do Sul) (Campos-Filho et al., 2015b).

\section{Benthana tupinamba Campos-Filho, Taiti and Araujo, 2015}

Benthana tupinamba Campos-Filho, Taiti and Araujo, 2015b: 61, figs. 39, 40, 43. - Campos-Filho et al., 2017c: 8 .

Distribution. Endemic to Brazil (state of Bahia) (Campos-Filho et al., 2015b).

\section{Benthana werneri Lemos de Castro, 1958}

Benthana werneri Lemos de Castro, 1958b: 104, figs. 50-59. - Souza-Kury, 1998: 660. - Leistikow and Wägele, 1999: 15. - Schmalfuss, 2003: 54. - Magrini et al., 2010: 218. - Magrini et al., 2011: 65. - CamposFilho et al., 2015b: 26, figs. 14, 15, 16D.

Distribution. Endemic to Brazil (state of São Paulo) (Campos-Filho et al., 2015b).

\section{Genus Burmoniscus Collinge, 1914}

\section{Burmoniscus meeusei (Holthuis, 1947)}

Chaetophiloscia meeusei Holthuis, 1947: 124, figs. 1, 2. Burmoniscus meeusei - Araujo et al., 1996: 118, figs. 15-21, 64. - Souza-Kury, 1998: 660. - Schmalfuss, 2003: 63. - Zimmermann et al., 2012: 712, Tab. 1. - Zimmermann et al., 2015b: 703, fig. 5, Tab. 1. - Zimmermann et al., 2015a: 3, fig. 2, Tabs. 1, 2. Zimmermann et al., 2018a: 475, Tabs. 1, 2, figs. 5, 6.

Distribution. Introduced species recorded from the state of Santa Catarina (Araujo et al., 1996).

\section{Genus Chaetophiloscia Verhoeff, 1908a}

\section{6. "Chaetophiloscia” frontalis Lemos de Castro,} 1967

Chaetophiloscia frontalis Lemos de Castro, 1967: 320. - Souza-Kury, 1998: 660. - Leistikow and Wägele, 1999: 15. - Schmalfuss, 2003: 69. 
Distribution. Species originally described from the state of Pará (Lemos de Castro, 1967). To date, the validity of this species within the genus is dubious (Schmalfuss, 2003).

\section{7. "Chaetophiloscia" gatunensis (Van Name, 1926)}

Philoscia gatunensis Van Name, 1926: 12, figs. 21, 22. Chaetophiloscia gatunensis - Lemos de Castro, 1967: 321. - Souza-Kury, 1998: 661. - Schmalfuss, 2003: 69.

Distribution. Species originally described from the Barro Colorado Island Biological Station, Panama channel, Panama (Van Name, 1926). In Brazil, it is recorded from the states of Amazonas and Pará (Lemos de Castro, 1967). The validity of this species within the genus is dubious (Schmalfuss, 2003).

\section{Genus Ischioscia Verhoeff, 1928}

\section{Ischioscia amazonica}

Lemos de Castro, 1955

Ischioscia amazonica Lemos de Castro, 1955: 51, figs. 1-8. - Lemos de Castro, 1967: 318. - Schmalfuss, 1980: 131. - Souza-Kury, 1998: 661. - Leistikow and Wägele, 1999: 16. - Leistikow and Schmidt, 2002: 152, figs. 17-21. - Schmalfuss, 2003: 115. - Campos-Filho et al., 2014: 391.

Proischioscia amazonica - Vandel, 1968: 78, figs. 12, 13.

Distribution. Endemic to Brazil (states of Amazonas and Pará) (Lemos de Castro, 1955; Campos-Filho et al., 2014).

\section{Ischioscia irmleri Schmalfuss, 1980}

Ischioscia irmleri Schmalfuss, 1980: 136, figs. 27-32. - Souza-Kury, 1998: 661. - Leistikow and Wägele, 1999: 17. - Schmalfuss, 2003: 115.

Distribution. Endemic to Brazil (Curari Island, Manaus, state of Amazonas) (Schmalfuss, 1980).

\section{Genus Leonardoscia Campos-Filho, Araujo and Taiti, 2014}

\section{Leonardoscia hassalli Campos-Filho,} Araujo and Taiti, 2014

Leonardoscia hassalli Campos-Filho, Araujo and Taiti, in Campos-Filho et al., 2014: 379, figs. 14-16, 40. - Campos-Filho et al., 2016: 2. - Angarten et al., 2017: 17. - Campos-Filho et al., 2017b: 70. - Cavalcanti, 2017: 49, Tab. 2. - Gallão and Bichuette, 2018: 7, Tab. 1.

Distribution. Troglobitic and endemic species recorded from Leonardo da Vinci cave, Altamira karst region, state of Pará (Campos-Filho et al., 2014).

\section{Genus Metaprosekia Leistikow, 2000}

\section{Metaprosekia caupe Campos-Filho, Araujo and Taiti, 2014}

Metaprosekia caupe Campos-Filho, Araujo and Taiti, in Campos-Filho et al., 2014: 387, figs. 20-22, 40.

Distribution. Endogean species endemic to Sugiro cave, state of Pará (Campos-Filho et al., 2014).

\section{Metaprosekia quadriocellata Campos-Filho, Araujo and Taiti, 2014}

Metaprosekia quadriocellata Campos-Filho, Araujo and Taiti, in Campos-Filho et al., 2014: 383, figs. $17-19,40$.

Distribution. Endogean species endemic to Leonardo da Vinci cave, Altamira karst region, state of Pará (Campos-Filho et al., 2014).

\section{Genus Oniscus Linnaeus, 1758}

\section{Oniscus asellus Linnaeus, 1758}

Oniscus asellus Linnaeus, 1758: 637. - Zardo and Loyola e Silva, 1988: 791, figs. 1-4. - Souza-Kury, 1998: 658. - Leistikow and Wägele, 1999: 24. - Schmalfuss, 2003: 161. 
Distribution. European species introduced to many regions of the Americas (Schmalfuss, 2003). In Brazil, it is recorded from the state of Paraná (Zardo and Loyola e Silva, 1988).

\section{Genus Paratlantoscia Zimmermann, Campos- Filho and Araujo, 2018}

\section{Paratlantoscia ituberasensis (Campos-Filho, Lisboa and Araujo, 2013)}

Atlantoscia ituberasensis Campos-Filho, Lisboa and Araujo, 2013b: 466, fig. 12c. - Campos-Filho et al., 2017c: 8. - Zimmermann et al., 2015b: 704, figs. 5, 6, Tabs. 1-3.

Paratlantoscia ituberasensis - Zimmermann et al., 2018a: 475, Tabs. 1, 2, figs. 5, 6.

Distribution. Endemic to Brazil (state of Bahia) (Campos-Filho et al., 2013b; 2017c).

\section{Paratlantoscia robusta Zimmermann,} Campos-Filho and Araujo, 2018

Paratlantoscia robusta Zimmermann, Campos-Filho and Araujo, 2018a: 475, Tabs. 1, 2, figs. 1-6.

Distribution. Endemic to Brazil (Atlantic forest areas from the state of Bahia) (Zimmermann et al., 2018a).

\section{Paratlantoscia rubromarginata}

(Araujo and Leistikow, 1999)

Atlantoscia rubromarginata Araujo and Leistikow, 1999: 110, figs. 1-5. - Leistikow, 2001b: 6. Schmalfuss, 2003: 49. - Campos-Filho et al., 2012: 141. - Campos-Filho et al., 2013b: 466, fig. 12b. - Lisboa et al., 2013: 394. - Zimmermann et al., 2015b: 704, figs. 5, 6, Tabs. 1-3. - Zimmermann et al., 2015a: 3, Tab. 1.

Paratlantoscia rubromarginata - Zimmermann et al., 2018a: 474, Tabs. 1, 2, figs. 5, 6.

Distribution. Endemic to Brazil (states of Alagoas, Bahia, Pará, and Sergipe) (Campos-Filho et al., 2013b; 2017c).

\section{Genus Parischioscia Lemos de Castro, 1967}

\section{Parischioscia omissa (Van Name, 1936)}

Philoscia omissa Van Name, 1936: 140, figs. 67, 68. Parischioscia omissa - Lemos de Castro, 1967: 319. - Souza-Kury, 1998: 661. - Leistikow and Wägele, 1999: 20. - Schmalfuss, 2003: 173.

Distribution. Endemic to the Amazon Forest region, in Brazil, French Guiana and Guyana (Leistikow, 2001c; Schmalfuss, 2003). In Brazil, it is recorded from Serra do Navio, state of Amapá (Lemos de Castro, 1967).

\section{Genus Pseudotyphloscia Verhoeff, 1928}

\section{Pseudotyphloscia alba (Dollfus, 1898)}

Philoscia alba Dollfus, 1898:381, figs. 29a, b, pl. 15, fig. 29.

Pseudotyphloscia alba - Campos-Filho et al., 2017c: 9.

Distribution. Widespread species known from southern China, Indonesia (Sulawesi, Java, Krakatau Is, Bali), Philippines, Taiwan and glasshouses in England (Kwon and Taiti, 1993; Gregory, 2014). In Brazil, it is considered an introduced species recorded from the states of Minas Gerais and Paraná (Campos-Filho et al., 2017c).

\section{Genus Xiphoniscus Vandel, 1968}

\section{Xiphoniscus adisi Grangeiro, Souza and Christoffersen, 2017}

Xiphoniscus adisi Grangeiro, Souza and Christoffersen, 2017: 376, figs. 1-7.

Distribution. Endemic to Brazil (Tarumã Mirim River, state of Amazonas) (Grangeiro et al., 2017).

\section{Family Balloniscidae Vandel, 1963}

\section{Genus Balloniscus Budde-Lund, 1908}

\section{Balloniscus glaber Araujo and Zardo, 1995}

Balloniscus glaber Araujo and Zardo, 1995: 785, figs. 1-17. - Araujo, 1999a: 250, fig. 18. - Lopes et al., 2005: 
101, Tab. 1. - Almerão et al., 2006: 474, fig 4. - Almerão et al., 2012: 981, fig. 2, Tabs., 1, 2. - Meinhardt et al., 2007: 1108, figs. 1, 2, Tabs. 1, 2. - Quadros and Araujo, 2007: 242, figs. 1-3, Tabs. 1, 2. - Quadros and Araujo, 2008: 59, figs. 1, 2, Tabs. 1-4. - Quadros et al., 2009: 244, figs. 2, 3, Tabs. 1, 2. - Quadros, 2010: 573. - Appel et al., 2011: 125, Tab. 1. - Zimmermann et al., 2012: 712. - Zimmermann et al., 2015a: 3, Tabs. 1, 2. - Kenne and Araujo, 2015: 430, figs. 1-7, Tabs. 1, 2. - CamposFilho et al., 2017c: 9. - Wood et al., 2017: 4, figs. 1-3, 7 .

Distribution. Endemic to Brazil (states of Rio Grande do Sul and Santa Catarina) (Campos-Filho et al., 2017c).

\section{Balloniscus sellowi (Brandt, 1833)}

Philoscia sellowii Brandt, 1833: 43. - Budde-Lund, 1885: 218.

Philoscia (Balloniscus) sellowii-Budde-Lund, 1908: 289, pl. XVI, fig. 3. - Van Name, 1936: 136.

Philoscia paulensis - Moreira, 1927: 194, figs. 1-3. - Moreira, 1931: 426, figs. 1-8. - Lemos de Castro, 1958a: 7.

Balloniscus sellowii - Lemos de Castro, 1976: 392, figs. 1-13. - Araujo et al., 1996: 120, figs. 22-27, 65. Souza-Kury, 1998: 654. - Araujo, 1999a: 249, fig. 17. - Leistikow and Wägele, 1999: 31 . - Leistikow, 2001b: 3, Tab. 1. - Schmalfuss, 2003: 51. - Lopes et al., 2005: 101, Tab. 1. - Almerão et al., 2012: 981, fig. 2, Tabs. 1, 2. - Wood et al., 2012: 234, fig. 2. - Zimmermann et al., 2015a: 703, fig. 2, Tabs. 1, 2. - Campos-Filho et al., 2017c: 9. - Zimmermann et al., 2018a: 475, Tabs. 1, 2, figs. 5, 6.

Distribution. Endemic to South America, recorded from Argentina, Brazil, Paraguay, and Uruguay (Schmalfuss, 2003). In Brazil, it is distributed from Minas Gerais to Rio Grande do Sul states (CamposFilho et al., 2017c).

\section{Family Halophilosciidae Verhoeff, 1908a}

\section{Genus Littorophiloscia Hatch, 1947}

\section{Littorophiloscia culebrae (Moore, 1901)}

Philoscia culebrae Moore, 1901: 176, pl. 11, figs. 13-17.
Littorophiloscia culebrae - Araujo and Taiti, 2007: 348. - Lisboa et al., 2017: 354, fig. 1.

Distribution. Circumtropical species (Schmalfuss, 2003). In Brazil, it is recorded from Rocas Atoll, state of Rio Grande do Norte (Araujo and Taiti, 2007).

\section{Littorophiloscia denticulata (Ferrara and Taiti, 1982)}

Bilawrencia denticulata Ferrara and Taiti, 1982: 469, figs. 6, 7A-J.

Littorophiloscia denticulata - Lisboa et al. 2017: 354, fig. 1.

Distribution. Species originally described from Andaman Islands (Ferrara and Taiti, 1982). It is recorded from Guatemala (Schmidt and Leistikow, 2004), and Brazil (state of Bahia) (Lisboa et al., 2017). Based on these records, it can be considered a species with circumtropical distribution.

\section{Littorophiloscia insularis (Lemos de Castro and Souza, 1986)}

Prosekia insularis Lemos de Castro and Souza, 1986: 435, figs. 5, 6. - Souza-Kury, 1998: 662. - Leistikow and Wägele, 1999: 22. - Schmalfuss, 2003: 216.

Littorophiloscia insularis - Leistikow, 2001a: 120. - Lisboa et al., 2017: 354, fig. 1.

Distribution. Endemic to Brazil (Fortaleza Island, São João de Pirabas, state of Pará) (Lemos de Castro and Souza, 1986).

\section{Littorophiloscia tropicalis Taiti and Ferrara, 1986}

Littorophiloscia compar compar - Lemos de Castro, 1965: 94, figs. 31-33.

Littorophiloscia tropicalis Taiti and Ferrara, 1986: 1361, figs. 1, 9. - Souza-Kury, 1998: 661. - Leistikow and Wägele, 1999: 18. - Schmalfuss, 2003: 133. Lisboa et al., 2017: 354, fig. 1 .

Remarks. Lemos de Castro's paper on Littorophiloscia compar was first published as a preprint in 1965, but the final volume was published in 1968. 
Distribution. Circumtropical species (Schmalfuss, 2003). In Brazil, it is recorded from the states of Bahia and Rio de Janeiro (Lemos de Castro, 1965; Lisboa et al., 2017).

\section{Family Scleropactidae Verhoeff, 1938}

\section{Genus Amazoniscus Lemos de Castro, 1967}

\section{Amazoniscus arlei Lemos de Castro, 1967}

Amazoniscus arlei Lemos de Castro, 1967: 326. - Lemos de Castro, 1969: 2, figs. 1-11. - SouzaKury, 1998: 665. - Leistikow and Wägele, 1999: 37. - Schmalfuss, 2003: 15. - Souza et al., 2006: 41, fig. 20. - Schmidt, 2007: 13, figs. 12, 189-196; CamposFilho et al., 2014:395. - Campos-Filho et al., 2017c: 10. nec Amazoniscus arlei - Schmidt, 2007: 64 (partim: specimens from Leopoldina, state of Minas Gerais).

Remarks. Schmidt (2007) redescribed Amazoniscus arlei Lemos de Castro, 1967 based on type material from the states of Amapá and Pará, and recorded the species also from the states of Minas Gerais and Rio de Janeiro. Campos-Filho et al. (2017c) recognized that the specimens of $A$. arlei from Minas Gerais examined by Schmidt belong to the new species $A$. schmidti Campos-Filho, Montesanto and Taiti, 2017. Most probably the record of $A$. arlei from the state of Rio de Janeiro represents a different species. However, further studies should be conducted to confirm this statement.

Distribution. Endemic to Brazil. Common species in the Brazilian Amazon Forest (states of Amapá, Pará, and Tocantins), and in the state of Rio de Janeiro (Lemos de Castro, 1967; Souza et al., 2006; Schmidt, 2007).

\section{Amazoniscus eleonorae Souza, Bezerra and Araújo, 2006}

Amazoniscus eleonorae Souza, Bezerra and Araújo, 2006: 37, figs. 1-20. - Campos-Filho et al., 2014: 361, fig. 40. - Pires et al., 2015: 69, Tab. 1. - Campos-Filho et al., 2016: 2. - Angarten et al., 2017: 17. - Bastos-Pereira et al., 2017: 292. - Campos-Filho et al., 2017b: 70. Cavalcanti, 2017: 49, Tab. 2. - Gallão and Bichuette, 2018: 7, Tab. 1 .
Distribution. Troglobitic species endemic to Pedra da Cachoeira, Planaltina, and Limoeiro caves, Altamira karst region, state of Pará (Souza et al., 2006).

\section{Amazoniscus leistikowi Campos-Filho, Araujo and Taiti, 2014}

Amazoniscus leistikowi Campos-Filho, Araujo and Taiti, in Campos-Filho et al., 2014: 391, figs. 23-25, 40. - Campos-Filho et al., 2016: 2. - Angarten et al., 2017: 17. - Campos-Filho et al., 2017c: 11. - CamposFilho et al., 2017b: 70. - Cavalcanti, 2017: 49, Tab. 2. - Gallão and Bichuette, 2018: 7, Tab. 1.

Distribution. Troglobitic species endemic to Abrigo do Sismógrafo cave, Altamira karst region, state of Pará (Campos-Filho et al., 2014).

\section{Amazoniscus schmidti Campos-Filho, Montesanto and Taiti, 2017}

Amazoniscus schmidti Campos-Filho, Montesanto and Taiti, in Campos-Filho et al., 2017c: 12, figs. 51-73.

Amazoniscus arlei - Schmidt, 2007: 64, figs. 192195 (partim: specimens from Leopoldina, state of Minas Gerais).

Distribution. Endemic to Brazil (state of Minas Gerais) (Schmidt, 2007; Campos-Filho et al., 2017c).

\section{Amazoniscus zimmeri Campos-Filho, Montesanto and Araujo, 2017}

Amazoniscus zimmeri Campos-Filho, Montesanto and Araujo, in Campos-Filho et al., 2017c: 10, figs. $28-50$.

Distribution. Endemic to Brazil (state of Pará) (Campos-Filho et al., 2017c).

\section{Genus Circoniscus Pearse, 1917}

\section{Circoniscus bezzii Arcangeli, 1931}

Circoniscus bezzii Arcangeli, 1931: 115, pl. II. - Van Name, 1936: 311, fig. 184. - Vilela et al., 1971: 185. - Souza and Lemos de Castro, 1991: 50, figs. 23-44. - Schultz, 1995: 417, fig. 12J-M. - Souza-Kury, 1998: 666. - Leistikow and Wägele, 1999: 38. - Schmalfuss, 
2003: 81. - Schmidt, 2007: 72, figs. 224-229. Campos-Filho et al., 2014: 396, fig. 40, Tabs. 1, 2. Zimmermann et al., 2015a: 3, fig. 2, Tabs. 1, 2.

Distribution. Endemic to South America, recorded from Brazil and Paraguay (Schmalfuss, 2003). In Brazil, it is recorded from the states of Minas Gerais, Pará, and São Paulo (Campos-Filho et al., 2014).

\section{Circoniscus buckupi Campos-Filho and Araujo, 2011}

Circoniscus buckupi Campos-Filho and Araujo, 2011b: 28, figs. 1-3, 7. - Pires et al., 2015: 69, Tab. 1. - Campos-Filho et al. 2016: 2. - Angarten et al., 2017: 17. - Bastos-Pereira et al., 2017: 292. - CamposFilho et al., 2017b: 70. - Cavalcanti, 2017: 49, Tab. 2. - Bueno et al., 2018: 6, Tab. 2. - Gallão and Bichuette, 2018: 7, Tab. 1.

Distribution. Troglobitic species endemic to Brazil with several records in caves from Parauapebas region, state of Pará (Campos-Filho and Araujo, 2011b).

\section{Circoniscus carajasensis Campos-Filho and Araujo, 2011}

Circoniscus carajasensis Campos-Filho and Araujo, 2011 b: 34, figs. 4-7. - Campos-Filho et al. 2014:396, fig. 40. - Pires et al., 2015: 69, Tab. 1. - Campos-Filho et al., 2016: 2. - Angarten et al., 2017: 17. - Bastos-Pereira et al., 2017: 292. - Campos-Filho et al., 2017b: 70. Cavalcanti, 2017: 49, Tab. 2. - Gallão and Bichuette, 2018: 7, Tab. 1.

Distribution. Troglobitic species endemic to Brazil with records from caves in Canaã dos Carajás region, state of Pará (Campos-Filho and Araujo, 2011b).

\section{Circoniscus hirsutus Schmidt, 2007}

Circoniscus hirsutus Schmidt, 2007: 66, figs. 197-202.

Distribution. Endemic to Brazil (Janauari Lake, Manaus, state of Amazonas) (Schmidt, 2007).

\section{Circoniscus incisus Souza and Lemos de Castro, 1991}

Circoniscus incisus Souza and Lemos de Castro, 1991: 56, figs. 69-90. - Souza-Kury, 1998: 666. Leistikow and Wägele, 1999: 38. - Schmalfuss, 2003: 82. - Schmidt, 2007: 71, figs. 218-223.

Circoniscus gracilidens Souza and Lemos de Castro, 1991: 56. - Souza-Kury, 1998: 666. - Leistikow and Wägele, 1999: 38. - Schmidt and Wägele, 2001: 317, fig. 5a, b. - Schmalfuss, 2003: 81. - Schmidt, 2007: 85. - Campos-Filho et al., 2014: 396, fig. 40.

Distribution. Endemic to Brazil (states of Pará and Rio de Janeiro) (Campos-Filho et al., 2014).

\section{Circoniscus intermedius Souza and Lemos de Castro, 1991}

Circoniscus intermedius Souza and Lemos de Castro, 1991: 53, figs. 45-68. - Souza-Kury, 1998: 666. Leistikow and Wägele, 1999: 38. - Schmalfuss, 2003: 82. - Schmidt, 2007: 70, fig. 217. - Campos-Filho et al., 2014: 396, fig. 40.

Distribution. Endemic to Brazil (states of Mato Grosso, Mato Grosso do Sul, and Pará) (CamposFilho et al., 2014).

\section{Circoniscus ornatus (Verhoeff, 1941)}

Parcirconiscus ornatus Verhoeff, 1941b: 169, figs. 1-9.

Circoniscus gaigei - Andersson, 1960a: 565, figs. 13, 14. - Lemos de Castro, 1967: 324. - Schmalfuss, 1980: 7, figs. 7, 8, 13. - Souza and Lemos de Castro, 1991: 47, figs. 1-22. - Warburg et al., 1997: 52. - SouzaKury, 1998: 666. - Leistikow and Wägele, 1999: 38. - Schmalfuss, 2003: 71

Circoniscus amazonicus Lima, 1996b: 92, figs. 1-26. - Souza-Kury, 1998: 666. - Leistikow and Wägele, 1999: 37. - Schmalfuss, 2003: 71.

Not: syn. of Circoniscus gaigei - Schmalfuss, 1980: 4. - Leistikow and Wägele, 1999: 37.

Distribution. Endemic to South America, recorded from Brazil, Peru and Suriname (Schmidt, 2007). In 
Brazil, it is recorded from the states Amapá, Amazonas, and Pará (Souza-Kury, 1998).

\section{Circoniscus pallidus Arcangeli, 1936}

Circoniscus pallidus Arcangeli, 1936: 204, figs. 5-9. - Souza and Lemos de Castro, 1991: 46, fig. 108. Leistikow and Wägele, 1999: 38. - Schmalfuss, 2003: 72. - Schmidt, 2007: 89.

Distribution. Endemic to Brazil (state of São Paulo) (Arcangeli, 1936).

\section{Genus Heptapactes Schmidt, 2007}

\section{Heptapactes quadrisaetosus Schmidt, 2007}

Heptapactes quadrisaetosus Schmidt, 2007: 19, figs. 18-24.

Distribution. Endemic to Brazil (state of Amazonas) (Schmidt, 2007).

\section{Genus Microsphaeroniscus Lemos de Castro, 1984}

100. Microsphaeroniscus bicolor Lemos de Castro, 1984

Microsphaeroniscus bicolor Lemos de Castro, 1984b: 3, figs. 18-21.

Distribution. Endemic to Brazil (state of São Paulo) (Lemos de Castro, 1984b).

\section{Microsphaeroniscus costatus Lemos de Castro, 1984}

Microsphaeroniscus costatus Lemos de Castro, 1984b: 3, figs. 22-26.

Distribution. Endemic to Brazil (Parque Nacional do Itaitiaia, state of Rio de Janeiro (Lemos de Castro, 1984b).

\section{Microsphaeroniscus pallidus} Lemos de Castro, 1984

Microsphaeroniscus pallidus Lemos de Castro, 1984b: 2, figs. 1-14.
Distribution. Endemic to Brazil (states of Rio de Janeiro and São Paulo) (Lemos de Castro, 1984b).

\section{Microsphaeroniscus squamatus Lemos de Castro, 1984}

Microsphaeroniscus squamatus Lemos de Castro, 1984b: 4, figs. 27-38.

Distribution. Endemic to Brazil, recorded from Itacuruça Island (Sepetiba Bay) and Reserva Biológica de Jacarepaguá, state of Rio de Janeiro (Lemos de Castro, 1984b).

\section{Microsphaeroniscus violaceus Lemos de Castro, 1984}

Microsphaeroniscus violaceus Lemos de Castro, 1984b: 3, figs. 15-17.

Distribution. Endemic to Brazil (Estação Ecológica da Boracéia, Serra do Mar, state of São Paulo) (Lemos de Castro, 1984b).

Family Rhyscotidae Budde-Lund, 1904

\section{Genus Rhyscotus Budde-Lund, 1885}

\section{Rhyscotus albidemaculatus Budde-Lund, 1908}

Rhyscotus albidemaculatus Budde-Lund, 1908: 302, pl. 17, fig. 46. - Souza-Kury, 1997a: 106, figs. 1-10. Souza-Kury, 1998: 665. - Leistikow and Wägele, 1999: 32. - Jeppesen, 2000: 230. - Schmalfuss, 2003: 229.

Distribution. Halophilous species endemic to Brazil, recorded from the littoral zone of the states of Bahia and Rio de Janeiro (Souza-Kury, 1998).

\section{Family Dubioniscidae Schultz, 1995}

\section{Genus Calycuoniscus Collinge, 1915}

\section{Calycuoniscus bodkini Collinge, 1915}

Calycuoniscus bodkini Collinge, 1915: 509, pl. 50, figs. 1-12. - Lemos de Castro, 1968: 410, figs. 8-15. - 
Souza-Kury, 1998: 655. - Leistikow and Wägele, 1999: 24. - Schmalfuss, 2003: 67. - Souza and Grangeiro, 2006: 38. - Campos-Filho, 2008: 49, figs. 61-64, Tab. 1. - Zimmermann et al., 2015a: 3, Tab. 1.

Phalloniscus bodkini - Lemos de Castro, 1960: 204.

Distribution. Species originally described from the Botanical Garden of Georgetown, Guyana (Collinge, 1915), and also recorded from Brazil (states of Amapá, Ceará and Pará) and Trinidad (Souza-Kury, 1998; Schmalfuss, 2003; Zimmermann et al., 2015a).

\section{Calycuoniscus goeldii}

(Lemos de Castro, 1967)

Hileioniscus goeldii Lemos de Castro, 1967: 318.

Calycuoniscus goeldii - Lemos de Castro, 1968: 408, figs. 1-7. - Schultz, 1995: 399-400. - Souza-Kury, 1998: 656. - Cardoso et al., 2016: 113.

Dubioniscus goeldii - Schultz, 1995: 401. - Leistikow and Wägele, 1999: 24. - Schmalfuss, 2003: 92. - Souza and Grangeiro, 2006: 37, figs. 3, 4. - Campos-Filho et al., 2014: 401, fig. 40.

Distribution. Endemic to Brazil (Parque do Museu Goeldi, Belém, state of Pará) (Lemos de Castro, 1968).

\section{Genus Dubioniscus Vandel, 1963}

\section{Dubioniscus delamarei Vandel, 1963}

Dubioniscus delamarei Vandel, 1963: 78, figs. 9-11. - Lemos de Castro, 1970a: 2. - Lenko, 1971: 7. - SouzaKury, 1998: 656. - Leistikow and Wägele, 1999: 24. - Schmalfuss, 2003: 92. - Cardoso et al., 2016: 113, figs. 1, 2, 13.

Distribution. Endemic to South America, recorded from Argentina, Brazil, and Paraguay (Schmalfuss, 2003). In Brazil, it is recorded from the states of Espírito Santo and São Paulo (Cardoso et al., 2016).

\section{Dubioniscus depressus Cardoso, Campos-Filho and Araujo, 2016}

Dubioniscus depressus Cardoso, Campos-Filho and Araujo, 2016: 122, figs. 7-9, 13.
Distribution. Endemic to Brazil (Serra da Mantiqueira region, state of São Paulo) (Cardoso et al., 2016).

\section{Dubioniscus elongatus Cardoso, Campos-Filho and Araujo, 2016}

Dubioniscus elongatus Cardoso, Campos-Filho and Araujo, 2016: 126, figs. 10-13.

Distribution. Endemic to Brazil (Parque Nacional do Itatiaia, state of Rio de Janeiro (Cardoso et al., 2016).

\section{1. Dubioniscus marmoratus Lemos de Castro, 1970}

Dubioniscus marmoratus Lemos de Castro, 1970a: 3, figs. 1-10. - Schultz 1995: 401. - Souza-Kury 1998: 656. - Leistikow and Wägele 1999: 25. - Schmalfuss 2003: 92. - Campos-Filho et al. 2014: 401, fig. 40. Cardoso et al., 2016: 117, figs. 3, 4, 13.

Distribution. Endemic to Brazil (state of Rio de Janeiro) (Cardoso et al., 2016).

\section{Genus Novamundoniscus Schultz, 1995}

\section{Novomundoniscus altamiraensis Campos- Filho, Araujo and Taiti, 2014}

Novomundoniscus altamiraensis Campos-Filho, Araujo and Taiti, in Campos-Filho et al., 2014: 397, figs. 26-28, 40.

Distribution. Endemic to Brazil (Abrigos Assurini cave, state of Pará) (Campos-Filho et al., 2014).

\section{Novamundoniscus dissimilis (Lemos de Castro, 1960)}

Phalloniscus dissimilis Lemos de Castro, 1960: 207, pl. 3, figs. 28-35. - Lenko, 1971: 6. - Zardo, 1989: 613. - Schultz, 1995: 407.

Novamundoniscus dissimilis - Souza-Kury, 1998: 656. - Leistikow and Wägele, 1999: 25. - Schmalfuss, 2003: 158.

Distribution. Endemic to Brazil (Barra do Sana, Macaé, state of Rio de Janeiro) (Lemos de Castro, 1960). 
114. Novamundoniscus gracilis Lopes and Araujo, 2003

Novamundoniscus gracilis Lopes and Araujo, 2003: 611, figs. 1-20. - Schmalfuss, 2003: 158. - Lopes et al., 2005: 101, Tab. 1. - Zimmermann et al., 2015a: 3, Tabs. 1, 2 .

Distribution. Endemic to Brazil (state of Rio Grande do Sul) (Lopes and Araujo, 2003; Zimmermann et al., 2015a).

\section{Novamundoniscus macrophthalmus (Lemos de Castro, 1960)}

Phalloniscus macrophthalmus Lemos de Castro, 1960: 205, 10-18; Schultz, 1995: 407.

Novamundoniscus macrophthalmus - Souza-Kury, 1998: 656. - Leistikow and Wägele, 1999: 25. Schmalfuss, 2003: 158.

Distribution. Endemic to Brazil (Barra do Sana, Macaé, state of Rio de Janeiro) (Lemos de Castro, 1960).

\section{Novamundoniscus meridionalis} (Araujo and Buckup, 1994)

Phalloniscus meridionalis Araujo and Buckup, 1994b: 271, figs. 14-28. - Araujo, 1999a: 247, fig. 13. - SouzaKury et al., 1998: 657. - Leistikow and Wägele, 1999: 26. - Schmalfuss, 2003: 179.

Novamundoniscus meridionalis - Lopes and Araujo, 2003: 611. - Bueno et al., 2018: 5, Tab. 1.

Distribution. Endemic to Brazil (states of Rio Grande do Sul and Santa Catarina) (Araujo and Buckup, 1994b).

\section{Novamundoniscus persimilis (Vandel, 1952)}

Phalloniscus persimilis Vandel, 1952a: 144, fig. 57. - Lemos de Castro, 1967: 322. - Schultz, 1995: 407.

Novamundoniscus persimilis - Souza-Kury, 1998: 656. - Leistikow and Wägele, 1999: 25. - Schmalfuss, 2003: 158.
Distribution. Endemic to northern South America, recorded from Brazil and Venezuela (Schmalfuss, 2003). In Brazil, it is recorded from the Parque do Museu Goeldi, Belém, state of Pará (Lemos de Castro, 1960).

\section{Novamundoniscus singularis}

(Lemos de Castro, 1967)

Phalloniscus singularis Lemos de Castro, 1967: 321. - Lemos de Castro, 1970b: 119, figs. 1-11. - Schultz, 1995: 407.

Novamundoniscus singularis - Souza-Kury, 1998: 656. - Leistikow and Wägele, 1999: 25. - Schmalfuss, 2003: 159.

Distribution. Endemic to Brazil (state of Amazonas) (Lemos de Castro, 1967; 1970b).

\section{Novamundoniscus vandeli} (Lemos de Castro, 1960)

Phalloniscus vandeli Lemos de Castro, 1960: 205, figs. 1-9. - Schultz, 1995: 407. - Araujo and Buckup, 1994b: 274.

Novamundoniscus vandeli - Schultz, 1995: 407, figs. 8, 9. - Souza-Kury, 1998: 656. - Leistikow and Wägele, 1999: 25. - Schmalfuss, 2003: 159.

Distribution. Endemic to southern South America, recorded from Brazil and Paraguay (Schmalfuss, 2003). In Brazil, it is recorded from the states of Minas Gerais and Rio de Janeiro (Lemos de Castro, 1960).

\section{Fmily Platyarthridae Verhoeff, 1949}

\section{Genus Niambia Budde-Lund, 1904}

\section{Niambia squamata (Budde-Lund, 1885)}

Porcellio (Leptotrichus) squamatus Budde-Lund, 1885: 196.

Niambia squamata - Lemos de Castro, 1967: 315. - Lemos de Castro, 1971: 3, fig. 5. - Lemos de Castro, 1972a: 357. - Souza-Kury, 1998: 662. - Schmalfuss, 2003: 157. - Araujo and Taiti, 2007: 350, figs. 7-13.

Niamba [sic!] squamata. - Leistikow \& Wägele, 1999: 28. 
Distribution. Introduced species recorded from the states of Bahia, Pará, Pernambuco and Rio Grande do Norte (Lemos de Castro, 1971; 1972a; Araujo and Taiti, 2007).

\section{Genus Trichorhina Budde-Lund, 1908}

\section{Trichorhina acuta Araujo and Buckup, 1994}

Trichorhina acuta Araujo and Buckup, 1994b: 130, figs. 1-12. - Souza-Kury, 1998: 662. - Araujo, 1999a: 251, fig. 21. - Leistikow and Wägele, 1999: 28. - Schmalfuss, 2003: 275. - Souza et al., 2011: 240, Tab. 1. - Campos-Filho et al., 2014: 408. - Zimmermann et al., 2015a: 3, Tab. 1. - Bueno et al., 2018: 5, Tab. 1.

Distribution. Endemic to Brazil (states of Rio Grande do Sul and Santa Catarina) (Araujo and Buckup, 1994b; Zimmermann et al., 2015a).

\section{Trichorhina amazonica Souza-Kury, 1997}

Trichorhina amazonica Souza-Kury, 1997b: 183, figs. 2, 8-20. - Souza-Kury, 1998: 662. - Leistikow and Wägele, 1999: 28. - Schmalfuss, 2003: 275. Souza et al., 2011: 241, Tab. 1. - Campos-Filho et al., 2014: 405.

Trichorhina barbouri - Lemos de Castro, 1967: 316.

Distribution. Endemic to the Brazilian Amazon (Souza et al., 2011). The type locality is probably Belém, state of Pará (Souza-Kury, 1997b).

\section{Trichorhina anhanguera Campos-Filho, Araujo and Taiti, 2014}

Trichorhina anhanguera Campos-Filho, Araujo and Taiti, in Campos-Filho et al., 2014: 408, figs. 34-36, 40. - Campos-Filho et al., 2015a: 112. - Campos-Filho et al., 2016: 12 .

Distribution. At present, known from Gruta MP-10 cave, Morro do Pilar, state of Minas Gerais (CamposFilho et al., 2014). This is probably a troglophile species from subterranean environments. Future surveys outside caves shall confirm this statement.

\section{Trichorhina argentina Vandel, 1963}

Trichorhina argentina Vandel, 1963: 73, fig. 6. - Araujo and Buckup, 1996a: 800, figs. 1-15, 41. Araujo, 1999a: 251, fig. 20. - Leistikow and Wägele, 1999: 28. - Schmalfuss, 2003: 275. - Lopes et al., 2005: 101, Tab. 1. - Souza et al., 2011: 241, Tab. 1. - Campos-Filho et al., 2014: 405. - Campos-Filho et al., 2017c: 18. - Zimmermann et al., 2015a: 3, Tab. 1.

Distribution. Endemic to southern South America, recorded from Argentina and Brazil (Schmalfuss, 2003). In Brazil, it is recorded from the states of Rio Grande do Sul and Santa Catarina (Campos-Filho et al., 2017c).

\section{Trichorhina bicolor Araujo and Buckup, 1996}

Trichorhina bicolor Araujo and Buckup, 1996a: 806, figs. 26-41. - Leistikow and Wägele, 1999: 28. - Schmalfuss, 2003: 275. - Souza et al., 2011: 241, Tab. 1. - Campos-Filho et al., 2017c: 18. - Bueno et al., 2018: 5, Tab. 1.

Distribution. Endemic to Brazil (states of Paraná and Santa Catarina) (Campos-Filho et al., 2017c).

\section{Trichorhina biumbonata Souza, Araújo and Campos-Filho, 2011}

Trichorhina biumbonata Souza, Araujo and CamposFilho, 2011: 240, figs. 1, 8-24, Tab. 1.

Distribution. Endemic to Brazil (state of São Paulo) (Souza et al., 2011).

\section{Trichorhina brasilensis Andersson, 1960}

Trichorhina brasilensis Andersson, 1960a: 552, fig. 8. - Schultz, 1995: 411, figs. 10, 11. - Souza-Kury, 1998: 663. - Leistikow and Wägele, 1999: 29. - Schmalfuss, 2003: 275. - Souza et al., 2011: 241, Tab. 1. - CamposFilho et al., 2014: 405. - Campos-Filho et al., 2015a: 117. - Campos-Filho et al., 2016: 12.

Distribution. Endemic to southern South America, recorded from Brazil and Paraguay (Schmalfuss, 2003). 
In Brazil, it is recorded from the state of Santa Catarina (Andersson, 1960a).

\section{Trichorhina cipoensis Campos-Filho, Bichuette and Taiti, 2016}

Trichorhina cipoensis Campos-Filho, Bichuette and Taiti, 2016: 7, figs. 8-10, 14.

Distribution. Troglophile species endemic to Brazil (Lapa do Cipó cave, state of Minas Gerais) (CamposFilho et al., 2016).

\section{Trichorhina crassisetae Souza, Araújo and Campos-Filho, 2011}

Trichorhina crassisetae Souza, Araújo and CamposFilho, 2011:244, figs. 2, 25-43, Tab. 1. - Campos-Filho et al., 2014: 405 .

Distribution. Endemic to Brazil (state of Mato Grosso do Sul) (Souza et al., 2011).

\section{Trichorhina curupira Campos-Filho, Araujo and Taiti, 2014}

Trichorhina curupira Campos-Filho, Araujo and Taiti, in Campos-Filho et al., 2014: 405, figs. 32, 33, 40. - Campos-Filho et al., 2015a: 112. - Campos-Filho et al., 2016: 12 .

Distribution. Troglophile species endemic to Pedra da Cachoeira cave, Altamira karst region, state of Pará (Campos-Filho et al., 2014).

\section{Trichorhina guanophila Souza-Kury, 1993}

Trichorhina guanophila Souza-Kury, 1993: 198, figs. 11-27. - Pinto-da-Rocha, 1995: 98. - SouzaKury, 1998: 663. - Leistikow and Wägele, 1999: 29. - Schmalfuss, 2003: 276. - Souza et al., 2011:241, Tab. 1. - Campos-Filho et al., 2014: 408, fig. 40. - CamposFlho et al., 2015a: 112. - Campos-Filho et al., 2016: 2. - Trajano et al., 2016: 1815. - Angarten et al., 2017: 17. - Bastos-Pereira et al., 2017: 292. - Campos-Filho et al., 2017b: 70. - Cavalcanti, 2017: 49, Tab. 2.

Distribution. Troglophile species endemic to Lapa do Convento cave, state of Bahia (Souza-Kury, 1993).

\section{Trichorhina heterophthalma Lemos de Castro, 1964}

Trichorhina heterophthalma Lemos de Castro, 1964: 2, figs. 1, 2. - Souza-Kury, 1993: 198, figs. 1-10. Leistikow and Wägele, 1999: 29.- Schmidt, 2001: 6. - Schmalfuss, 2003: 276. - Souza et al., 2011: 241, Tab. 1. - Campos-Filho et al., 2014: 408. - Grangeiro et al., 2014: 91. - Campos-Filho et al., 2015a: 112.

Distribution. Pantropical species (Schmalfuss, 2003). In Brazil, it is recorded from the states of Bahia and Rio de Janeiro (Souza-Kury, 1993).

\section{Trichorhina kaingangi Campos-Filho, 2015}

Trichorhina kaingangi Campos-Filho, in CamposFilho et al., 2015a: 114, figs. 2-4. - Campos-Filho et al. 2016: 12. - Campos-Filho et al., 2017c: 18.

Distribution. Troglophile species endemic to Brazil (Ermida Paiol do Alto and Água Boa caves, state of Paraná) (Campos-Filho et al., 2017c).

\section{Trichorhina lenkoi Souza, Araújo and Campos-Filho, 2011}

Trichorhina lenkoi Souza, Araújo and Campos-Filho, 2011: 247, figs. 3, 44-57, Tab. 1. - Campos-Filho et al., 2014: 408 .

Distribution. Endemic to Brazil (state of São Paulo) (Souza et al., 2011).

\section{Trichorhina macrops Souza-Kury, 1993}

Trichorhina macrops Souza-Kury, 1993: 205, figs. 28-39. - Souza et al., 2011: 241, Tab. 1. - CamposFilho et al., 2014: 408.

Distribution. Endemic to Brazil (Serra dos Cavalos, Caruarú, state of Pernambuco) (Souza-Kury, 1993).

\section{Trichorhina myrmecophila Souza, Araújo and Campos-Filho, 2011}

Trichorhina myrmecophila Souza, Araújo and Campos-Filho, 2011: 247, figs. 4, 58-78, Tab. 1. 
Distribution. Endemic to Brazil (state of São Paulo) (Souza et al., 2011).

\section{Trichorhina orensis Souza, Araújo and Campos-Filho, 2011}

Trichorhina orensis Souza, Araújo and Campos Filho, 2011: 249, figs. 5, 79-94, Tab. 1.

Distribution. Endemic to Brazil (Itacuruça Island, state of Rio de Janeiro) (Souza et al., 2011).

\section{Trichorhina paraensis Souza-Kury, 1997}

Trichorhina paraensis Souza-Kury, 1997b: 186, figs. 3, 21-36. - Souza et al., 2011: 241, Tab. 1. - CamposFilho et al., 2014: 405, 408.

Distribution. Endemic to Brazil (Parque do Museu Goeldi, Belém, state of Pará) (Souza et al., 2011).

\section{Trichorhina pataxosi Campos-Filho, Bichuette and Taiti, 2016}

Trichorhina pataxosi Campos-Filho, Bichuette and Taiti, 2016: 13, figs. 11-14.

Distribution. Troglophile species endemic to Brazil (Gruta do Sufoco and Gruta do Nei caves, Pedro Leopoldo, state of Minas Gerais) (Campos-Filho et al., 2016).

\section{Trichorhina pittieri (Pearse, 1921)}

Leptotrichus pittieri Pearse, 1921: 460, fig. 1.

Trichorhina pittieri - Lemos de Castro, 1967: 316. - Souza-Kury, 1998: 663. - Leistikow and Wägele, 1999: 30. - Schmalfuss, 2003: 277. - Souza et al., 2011 : 241, Tab. 1.

Distribution. Endemic to South America, recorded from Brazil, Guyana and Venezuela (Schmalfuss, 2003). In Brazil, it is recorded from the state of Pará (Lemos de Castro, 1967).

\section{Trichorhina sexdens Souza, Araújo and Campos-Filho, 2011}

Trichorhina sexdens Souza, Araújo and CamposFilho, 2011: 252, figs. 6, 95-107, Tab. 1. - CamposFilho et al., 2014: 408.

Distribution. Endemic to Brazil (Búzios Island, state of São Paulo) (Souza et al., 2011).

\section{Trichorhina tatianae Araujo and Almerão, 2007}

Trichorhina tatianae Araujo and Almerão, 2007: 219, figs. 1-25. - Souza et al., 2011:241, Tab. 1.

Distribution. Endemic to Brazil (state of Santa Catarina) (Araujo and Almerão 2007).

\section{Trichorhina tomentosa (Budde-Lund, 1893)}

Alloniscus tomentosa Budde-Lund, 1893: 126.

Trichorhina tomentosa - Vandel, 1963: 72. - Lemos de Castro, 1967: 315. - Lemos de Castro, 1971: 10, fig. 6. - Lenko, 1971: 5. - Araujo and Buckup, 1996a: 803, figs. 16-25, 41. - Souza-Kury, 1993: 201. - SouzaKury, 1997b: 181, figs. 1, 4-7. - Souza-Kury, 1998: 663. - Araujo, 1999a: 252, fig. 22. - Leistikow and Wägele, 1999: 30. - Schmalfuss, 2003: 277. - Souza et al., 2011: 241, Tab. 1. - Grangeiro et al., 2014: 91. - Campos-Filho et al., 2015a: 112. - Zimmermann et al., 2015a: 3, Tab. 1. - Campos-Filho et al., 2017c: 18.

Distribution. Pantropical species (Schmalfuss, 2003). In Brazil, it is recorded from the states of Minas Gerais and Rio Grande do Sul (Zimmermann et al., 2015a).

\section{Trichorhina tropidocerata Souza, Araújo and Campos-Filho, 2011}

Trichorhina tropidocerata Souza, Araújo and Campos-Filho, 2011: 255, figs. 7, 108-124, Tab. 1.

Distribution. Endemic to Brazil (state of São Paulo) (Souza et al., 2011). 
145. Trichorhina yiara Campos-Filho, Araujo and Taiti, 2014

Trichorhina yiara Campos-Filho, Araujo and Taiti, in Campos-Filho et al., 2014: 401, figs. 29-31, 40. Campos-Filho et al., 2015a: 112. - Campos-Filho et al., 2016: 12 .

Distribution. Troglophile species and endemic to Brazil (Abrigo do Sismógrafo and Abrigo do Abutre caves, state of Pará) (Campos-Filho et al., 2014).

Family Pudeoniscidae Lemos de Castro, 1973

\section{Genus Brasiloniscus Cardoso, Campos-Filho and Araujo, 2018}

146. Brasiloniscus maculatus

(Lemos de Castro, 1973)

Brasiloniscus maculatus Lemos de Castro, 1973: 6, figs. 3, 4. - Leistikow and Wägele, 1999: 42. Schmalfuss, 2003: 57. - Schmidt and Leistikow, 2004: 17. - Campos-Filho et al., 2018b: 457. - Cardoso et al., 2018: 3, figs. 1, 2, 7A.

Distribution. Endemic to Brazil (Vitória Island, state of São Paulo) (Lemos de Castro, 1973; Cardoso et al., 2018).

\section{Brasiloniscus verrucosus}

(Lemos de Castro, 1973)

Brasiloniscus verrucosus Lemos de Castro, 1973: 9, fig. 5. - Leistikow and Wägele, 1999: 42. - Schmalfuss, 2003: 57. - Campos-Filho et al., 2018b: 457. - Cardoso et al., 2018: 6, figs. 3, 4, 7B.

Distribution. Endemic to Brazil (state of Rio de Janeiro) (Lemos de Castro, 1973; Cardoso et al., 2018).

\section{Brasiloniscus litorallis Cardoso, Campos- Filho and Araujo, 2018}

Brasiloniscus litorallis Cardoso, Campos-Filho and Araujo, 2018: 9, figs. 5, 6, 7C.
Distribution. Endemic to Brazil (state of Rio de Janeiro) (Cardoso et al., 2018).

\section{Genus Oxossioniscus Campos-Filho, Lisboa and Cardoso, 2018}

\section{Oxossioniscus akoko Campos-Filho, Lisboa and Cardoso, 2018}

Oxossioniscus akoko Campos-Filho, Lisboa and Cardoso, 2018b: 473, figs. 10-13, 14d.

Pudeoniscus obscurus - Lisboa et al., 2013: 394, figure 1D.

Distribution. Endemic to Brazilian Atlantic Forest areas in the state of Bahia (Campos-Filho et al., 2018b).

\section{Oxossioniscus pataxo Campos-Filho, Lisboa} and Cardoso, 2018

Oxossioniscus pataxo Campos-Filho, Lisboa and Cardoso, 2018b: 468, figs. 6-9, 14c.

Distribution. Endemic to Brazilian Atlantic Forest areas in the state of Bahia (Campos-Filho et al., 2018b).

\section{Genus Iansaoniscus Campos-Filho, Araujo and Taiti, 2017}

\section{Iansaoniscus georginae Campos-Filho, Araujo and Taiti, 2017}

Iansaoniscus georginae Campos-Filho, Araujo and Taiti, in Campos-Filho et al., 2017b: 78, figs. 6-8. -Campos-Filho et al., 2018b: 457. - Gallão and Bichuette, 2018: 7, Tab. 1.

Distribution. Troglobitic species endemic to Brazil (Borboletas cave, Paripiranga, state of Bahia) (CamposFilho et al., 2017b).

\section{Iansaoniscus iraquara Campos-Filho, Araujo and Taiti, 2017}

Iansaoniscus iraquara Campos-Filho, Araujo and Taiti, in Campos-Filho et al., 2017b: 74, figs. 3-5. 
- Campos-Filho et al., 2018b: 457. - Gallão and Bichuette, 2018: 7, Tab. 1.

Distribution. Troglobitic species endemic to Brazil (Buraco do Cão cave, state of Bahia) (Campos-Filho et al., 2017b).

\section{Genus Pudeoniscus Vandel, 1963}

\section{Pudeoniscus birabeni Vandel, 1963}

Pudeoniscus birabeni Vandel, 1963: 91, figs. 16-19. - Lemos de Castro, 1973: 3. - Furlan, 1996: 18. Souza-Kury, 1998: 665. - Leistikow and Wägele, 1999: 43. - Schmalfuss, 2003: 226. - Schmidt, 2002: 381. - Schmidt, 2003: 79, figs. 100-103. - Schmidt and Leistikow, 2004: 78. - Souza et al., 2010: 12. - Appel et al., 2011: 124. - Lisboa et al., 2013: 394, fig. 1C. Campos-Filho et al., 2018b: 462, figs. 1, 14a. - Cardoso et al., 2018: 13.

Distribution. Endemic to Brazil (states of Bahia, Paraná, Rio de Janeiro, São Paulo and Santa Catarina) (Lemos de Castro, 1973; Lisboa et al., 2013).

\section{Pudeoniscus obscurus Lemos de Castro, 1973}

Pudeoniscus obscurus Lemos de Castro, 1973: 4, figs. 1 and 2. - Souza-Kury, 1998: 665. - Leistikow and Wägele, 1999: 43. - Schmalfuss, 2003: 226. - Magrini et al., 2010: 218. - Magrini et al., 2011: 65, Tab. 2. Zimmermann et al., 2015a: 3, Tab. 1. - Campos-Filho et al., 2018b: 463, figs. 2-5, 14b.

Pudeonisucs [sic!] obscurus - Furlan, 1996: 18.

nec Pudeoniscus obscurus - Lisboa et al., 2013: 394, fig. $1 \mathrm{D}$.

Distribution. Endemic to Brazil (state of São Paulo) (Lemos de Castro, 1973).

Family Bathytropidae Vandel, 1952

Genus Neotroponiscus Arcangeli, 1936

155. Neotroponiscus argentinus

(Giambiagi de Calabrese, 1939)

Porcellio argentinus Giambiagi di Calabrese, 1939: 634, pl. 1.
Brasilocellio nodulosus Verhoeff, 1941a: 124, figs. 8-15. - Vandel, 1963: 82. - Andersson, 1960a: 560, fig. 11.

Neotroponiscus argentinus - Lemos de Castro, 1970c: 93, fig. 3. - Souza-Kury, 1998: 654. - Leistikow and Wägele, 1999: 26. - Schmalfuss, 2003: 153. - Mugnai et al., 2013: 855, fig. 1. - Cardoso et al., 2017: 122.

Distribution. Endemic to South America, recorded from Argentina and Brazil (Schmalfuss, 2003). In Brazil, it is recorded from the states of Espírito Santo, Pernambuco, Rio de Janeiro, São Paulo, and Santa Catarina (Vandel, 1963; Andersson, 1960a; Lemos de Castro, 1970c; Mugnai et al., 2013).

\section{Neotroponiscus carolii Arcangeli, 1936}

Neotroponiscus carolii Arcangeli, 1936: 15, figs. 1-4. Van Name, 1940: 115, fig. 7. - Lemos de Castro, 1970c: 90, figs. 1, 2. - Lenko, 1971: 8. - Souza-Kury, 1998: 655. - Leistikow and Wägele, 1999: 27. - Schmalfuss, 2003: 153. - Lisboa et al., 2013: 394, fig. 1A, Tab. 1. - Mugnai et al., 2013: 855. - Cardoso et al., 2017: 122.

Distribution. Endemic to Brazil (states of Bahia, Espírito Santo, and São Paulo) (Lemos de Castro, 1970c; Lenko, 1971; Lisboa et al., 2013).

\section{Neotroponiscus daguerrii (Giambiagi de Calabrese, 1939)}

Porcellio daguerrii Giambiagi di Calabrese, 1939: 308, fig. 12.

Neotroponiscus daguerrii - Lemos de Castro, 1970c: 94, fig. 5a. - Araujo et al., 1996: 122, figs. 28-38, 65. - Araujo, 1999a: 250, fig. 19. - Souza-Kury, 1998: 655. - Leistikow and Wägele, 1999: 27. - Schmalfuss, 2003: 153. - Lopes et al., 2005: 101, Tab. 1. - Mugnai et al., 2013: 855. - Cardoso et al., 2017: 122.

Distribution. Endemic to southern South America, recorded from Argentina and Brazil (Schmalfuss, 2003). In Brazil, it is recorded from the state of Rio Grande do Sul (Araujo et al., 1996; Lopes et al., 2005).

\section{Neotroponiscus iporangaensis Cardoso and Araujo, 2017}

Neotroponiscus iporangaensis Cardoso and Araujo, in Cardoso et al., 2017: 122, figs. 1-3, 6A, 7A-D. 
Distribution. Endemic to Brazil (Cafezal cave, Iporanga karst region, state of São Paulo) (Cardoso et al., 2017).

\section{Neotroponiscus lenkoi Lemos de Castro, 1970}

Neotroponiscus lenkoi Lemos de Castro, 1970d: 8, figs. 5, 6. - Souza-Kury, 1998: 655. - Leistikow and Wägele, 1999: 27. - Schmalfuss, 2003: 153. - Mugnai et al., 2013: 856, figs. 1, 2. - Cardoso et al., 2017: 122.

Distribution. Endemic to Brazil (states of Rio de Janeiro and São Paulo) (Mugnai et al., 2013).

\section{Neotroponiscus littoralis Lemos de Castro, 1970}

Neotroponiscus littoralis Lemos de Castro, 1970d: 1, figs. 1, 2. - Souza-Kury, 1998: 655. - Leistikow and Wägele, 1999: 27. - Schmalfuss, 2003: 153. - Mugnai et al., 2013: 855. - Zimmermann et al., 2015a: 3, fig. 2, Tabs. 1, 2. - Cardoso et al., 2017: 122.

Distribution. Endemic to Brazil (states of Bahia and Rio de Janeiro) (Lemos de Castro, 1970d; Zimmermann et al., 2015a).

\section{Neotroponiscus lobatus Lemos de Castro, 1970}

Neotroponiscus lobatos Lemos de Castro, 1970d: 5, fig. 3. - Souza-Kury, 1998: 655. - Leistikow and Wägele, 1999: 27. - Schmalfuss, 2003: 153. - Mugnai et al., 2013: 855. - Cardoso et al., 2017: 122.

Distribution. Endemic to Brazil (state of Espírito Santo) (Lemos de Castro, 1970d).

\section{Neotroponiscus perlatus Lemos de Castro, 1970}

Neotroponiscus perlatus Lemos de Castro, 1970d: 11, figs. 7, 8. - Souza-Kury, 1998: 655. - Leistikow and Wägele, 1999: 27. - Schmalfuss, 2003: 153. - Cardoso et al., 2017: 122.
Distribution. Endemic to Brazil (state of Espírito Santo) (Lemos de Castro, 1970d).

\section{Neotroponiscus plaumanni} (Andersson, 1960)

Brasilocelio plaumanni Andersson, 1960a: 563, fig. 12.

Neotroponiscus plaumanni - Lemos de Castro, 1970c: 93, fig. 4. - Souza-Kury, 1998: 655. - Leistikow and Wägele, 1999: 27. - Schmalfuss, 2003: 153. Mugnai et al., 2013: 855. - Cardoso et al., 2017: 122.

Distribution. Endemic to southern South America, recorded from Brazil and Uruguay (Schmalfuss, 2003). In Brazil, it is recorded from Nova Teutônia, state of Santa Catarina (Andersson, 1960a).

\section{Neotroponiscus tuberculatus Cardoso and Araujo, 2017}

Neotroponiscus tuberculatus Cardoso and Araujo, in Cardoso et al., 2017: 126, figs. 4, 5, 6B, 7E, F.

Distribution. Endemic to Brazil (PBR03 and PBR23 caves, Brumadinho, state of Minas Gerais) (Cardoso et al., 2017).

\section{Family Eubelidae Budde-Lund, 1899}

\section{Genus Ethelum Budde-Lund, 1899}

\section{Ethelum americanum (Dollfus, 1896)}

Mesarmadillo americanus Dollfus, 1896: 397, figs. $11 \mathrm{a}-\mathrm{d}$.

Ethelum americanum - Lemos de Castro, 1967: 312. - Souza-Kury, 1998: 657. - Leistikow and Wägele, 1999: 42. - Schmalfuss, 2003:95. - Campos-Filho et al., 2017c: 19.

Distribution. Endemic to the Lesser Antilles and northern South America (Schmalfuss, 2003). In Brazil, it is recorded from the state of Pará (Campos-Filho et al., 2017c). 


\section{Family Armadillidae Brandt, 1833}

Genus Ctenorillo Verhoeff, 1942

\section{Ctenorillo ferrarai Campos-Filho, Araujo and Taiti, 2014}

Ctenorillo ferrarai Campos-Filho, Araujo and Taiti, in Campos-Filho et al., 2014: 412, figs. 37-40. - Campos-Filho et al., 2017c: 20.

Distribution. Endemic to Brazil (Floresta Nacional Carajás, Canaã dos Carajás, state of Pará) (CamposFilho et al., 2014).

\section{Ctenorillo mineri (Van Name, 1936)}

Cubaris mineri Van Name, 1936: 383, fig. 233.

Venezillo mineri - Vandel, 1963: 94, fig. 20. - SouzaKury, 1998: 654. - Leistikow and Wägele, 1999: 49.

Ctenorillo mineri - Schmalfuss, 2003: 76.

Distribution. Endemic to northern South America, recorded from Brazil, Guyana and Venezuela (Schmalfuss, 2003). In Brazil, it is recorded from the states of Pernambuco and Rio de Janeiro (Vandel, 1963).

\section{Ctenorillo tuberosus (Budde-Lund, 1904)}

Armadillo tuberosus Budde-Lund, 1904: 109, pl. $\mathrm{X}$, figs. 1-4.

Venezillo tuberosus - Lemos de Castro, 1972a: 357. - Lemos de Castro, 1972b: 347. - Souza-Kury, 1998: 654. - Schmalfuss, 2003: 293. - Campos-Filho, 2008: 51, figs. 65-68, Tab. 1. - Grangeiro et al., 2014: 95, fig. 1e.

Ctenorillo tuberosus - Campos-Filho et al., 2017c: 20, figs. 74-97.

Remarks. Grangeiro et al. (2014) recorded some Armadillidae specimens from the state of Piauí. According to the photograph provided by the authors, these specimens belong to Ctenorillo tuberosus.

Distribution. Endemic to Central America and northern South America (Schmalfuss, 2003). In Brazil, it is recorded from the states of Bahia, Ceará, and Piauí (Lemos de Castro, 1972b; Grangeiro et al., 2014; Campos-Filho et al., 2017c).

\section{Genus Cubaris Brandt, 1833}

\section{Cubaris cinerea Brandt, 1833}

Cubaris cinerea Brandt, 1833: 190. - Van Name 1936: 389. - Souza-Kury, 1998: 653. - Schmalfuss, 2003: 78.

Armadillo cinereus - Milne-Edwards, 1840: 179. - Budde-Lund, 1885: 29. - Budde-Lund, 1904: 120.

Cubaris cinereus - Stuxberg, 1875: 44.

Cubaris cineraea [sic!] -Leistikow and Wägele, 1999: 44.

Distribution. Endemic to Brazil, without a defined type locality (Souza-Kury, 1998; Schmalfuss, 2003).

\section{Cubaris murina Brandt, 1833}

Cubaris murina Brandt, 1833: 190. - Moreira, 1931: 432. - Lemos de Castro, 1967: 328. - Lemos de Castro, 1971: 12, fig. 13. - Lemos de Castro, 1972a: 357. Vilela et al., 1971: 184. - Araujo et al., 1996: 129, figs. 46-47. - Souza-Kury, 1998: 653. - Leistikow and Wägele, 1999: 44. - Schmalfuss, 2003: 81. - Niemeyer et al., 2006: 14. - Niemeyer et al., 2009: 138. - Niemeyer and da Silva, 2006: 18. - Campos-Filho, 2008: 53, figs. 69-71, Tab. 1. - Appel et al., 2011: 124, fig. 2B, C. Campos-Filho et al., 2014: 417, fig. 40. - Grangeiro et al., 2014: 96. -Zimmermann et al., 2015a: 3, Tab. 1. - Campos-Filho et al., 2017c: 21.

Cubaris murinus - Stuxberg, 1875: 44.

Distribution. Circumtropical species (Schmalfuss, 2003). In Brazil, it is recorded from the states of Bahia, Espírito Santo, Mato Grosso, Mato Grosso do Sul, Pará, Paraná, Santa Catarina, and Tocantins (Campos-Filho et al., 2017c). Specimens of C. murina deposited in the UFRGS collection were sampled in Araguaína (1우, UFRGS 6547), and Wanderlândia (3 $3 \hat{0}$, UFRGS 6548), state of Tocantins.

\section{Genus Diploexochus Brandt, 1833 171. Diploexochus echinatus Brandt, 1833}

Diploexochus echinatus Brandt, 1833:192, pl. IV, figs. 20, 21. - Arcangeli, 1934: 92. - Arcangeli, 1957: 101. - Van Name, 1936: 398, figs. 241-243. - Lemos de Castro, 1967: 327. - Souza-Kury, 1998: 653. - 
Leistikow and Wägele, 1999: 44. - Schmalfuss, 2003: 90. - Campos-Filho et al., 2017c: 22, figs. 98-122.

Armadillo echinatus - Budde-Lund, 1879: 7. Budde-Lund, 1885: 26. - Budde-Lund, 1904: 104, pl. IX, figs. 35-37.

Distribution. Endemic to Central America and northern South America, recorded from Brazil, French Guiana, Guyana, and Trinidad (Schmalfuss, 2003). In Brazil, it is recorded from the Floresta Nacional Caxiuanã, state of Pará (Campos-Filho et al., 2017c).

\section{Genus Gabunillo Schmalfuss and Ferrara, 1983}

172. Gabunillo aridicola Souza, Senna and Kury, 2010

Gabunillo aridicola Souza, Senna and Kury, 2010: 2, figs. 1-9.

Distribution. Endemic to Brazil (states of Ceará and Rio Grande do Norte) (Souza et al., 2010).

\section{Genus Pseudodiploexochus Lewis, 1998}

\section{Pseudodiploexochus gibbus}

(Lemos de Castro, 1972)

Reductoniscus gibbus Lemos de Castro, 1972b: 347, figs. 1-5. - Ferrara and Taiti, 1990: 489.

Pseudodiploexochus gibbus - Ferrara and Taiti, 1990: 490. - Souza-Kury, 1998: 653. - Leistikow and Wägele, 1999: 45. - Schmalfuss, 2003: 223.

Distribution. Endemic to Brazil (old road from Santos to São Paulo, state of São Paulo) (Lemos de Castro, 1972b).

\section{Pseudodiploexochus tabularis (Barnard, 1932)}

Diploexochus tabularis Barnard, 1932:354, fig. 65a-e.

Pseudodiploexochus tabularis - Lopes et al., 2005: 101, Tab. 1.

Distribution. Species originally described from Cape Province, South Africa (Barnard, 1932). In Brazil, it is considered introduced and is recorded from Serra Geral, state of Rio Grande do Sul (Lopes et al., 2005).

\section{Genus Venezillo Verhoeff, 1928}

\section{Venezillo congener (Budde-Lund, 1904)}

Armadillo congener Budde-Lund, 1904: 108.

Cubaris congenera - Van Name, 1936: 340. - Vilela et al., 1971: 183.

Venezillo (Venezillo) congener - Arcangeli, 1957: 112.

Venezillo congeneris [sic!] - Souza-Kury, 1998: 654.

Venezillo congener - Leistikow and Wägele, 1999: 47. - Jeppesen, 2000: 236. - Schmalfuss, 2003: 287.

Distribution. Endemic to Brazil (Nabilecche River, state of Mato Grosso do Sul) (Budde-Lund, 1904; Souza-Kury, 1998).

Family Oniscidae Latreille, 1802

\section{Genus Phalloniscus Budde-Lund, 1908}

\section{Phalloniscus loyolai Zardo, 1989}

Phalloniscus loyolai Zardo, 1989: 611, figs. 1-25. - Souza-Kury, 1998: 657. - Leistikow and Wägele, 1999: 26. - Schmalfuss, 2003: 179.

Distribution. Endemic to Brazil (Parque Barigui, Curitiba, state of Paraná) (Zardo, 1989).

\section{Phalloniscus setosus Lemos de Castro, 1960}

Phalloniscus setosus Lemos de Castro, 1960: 207, figs. 20-27. - Zardo, 1989: 613. - Souza-Kury, 1998: 657. - Leistikow and Wägele, 1999: 26. - Schmalfuss, 2003: 179.

Distribution. Endemic to Brazil (state of Minas Gerais) (Lemos de Castro, 1960).

\section{Family Trachelipodidae Strouhal, 1953}

\section{Genus Nagurus Holthuis, 1949}

\section{Nagurus cristatus (Dollfus, 1889)}

Porcellio cristatus Dollfus, 1889: 91, pl. 5, fig. 2a-d. Nagara cristata - Vilela et al., 1971: 184, Quadro 1. 
Nagurus cristatus - Lemos de Castro, 1967: 323. Lemos de Castro, 1971: 7, fig. 7. - Araujo and Buckup, 1996b: 161, figs. 1, 3. - Souza-Kury, 1998: 668. Leistikow and Wägele, 1999: 36. - Campos-Filho et al., 2017c: 19.

Distribution. Pantropical species (Schmalfuss, 2003). In Brazil, it is recorded from the states of Amazonas, Bahia, Mato Grosso, Rio de Janeiro, São Paulo, and Santa Catarina (Lemos de Castro, 1967; 1971; Vilela et al., 1971; Araujo and Buckup, 1996b; Campos-Filho et al., 2017c).

\section{Nagurus nanus (Budde-Lund, 1908)}

Porcellio (Nagara) nana Budde-Lund, 1908: 285, pl. 14, figs. 40-47.

Nagurus nanus - Araujo and Buckup, 1996b: 161, figs. 2, 3. - Campos-Filho et al., 2017c: 19.

Distribution. Pantropical species (Schmalfuss, 2003). In Brazil, it is recorded from the states of Santa Catarina and Tocantins (Araujo and Buckup, 1996b; Campos-Filho et al., 2017c). Specimens of N. nanus deposited in the UFRGS collection were sampled in Araguaína, state of Tocantins $(1 \hat{\jmath}, 2$, UFRGS 6566).

\section{Genus Trachelipus Budde-Lund, 1908}

\section{Trachelipus rathkii (Brandt, 1833)}

Porcellio rathkii Brandt, 1833: 477.

Trachelipus rathkii - Lemos de Castro, 1971: 6, fig. 12. - Souza-Kury, 1998: 668. - Leistikow and Wägele, 1999: 37.

Distribution. European species introduced in the Americas (Schmalfuss, 2003). In Brazil, it is recorded from the state of Rio de Janeiro (Lemos de Castro, 1971).

\section{Family Porcellionidae Brandt, 1831}

\section{Genus Agabiformius Verhoeff, 1908b}

\section{Agabiformius lentus (Budde-Lund, 1885)}

Oniscus (Lyprobius) lentus Budde-Lund, 1885: 230-231.
Agabiformiuslentus - Lemos de Castro, 1971: 7, fig. 8 . - Araujo and Bueno, 1998: 185. - Souza-Kury, 1998: 663. - Araujo, 1999a: 256, fig. 30. - Leistikow and Wägele, 1999: 33. - Campos-Filho, 2008: 44, fig. 52, Tab. 1.

Distribution. Mediterranean species introduced all over the world (Schmalfuss, 2003). In Brazil, it is recorded from the states of Ceará, Rio de Janeiro, and Rio Grande do Sul (Lemos de Castro, 1971; Araujo and Bueno, 1998; Campos-Filho, 2008).

\section{Genus Porcellio Latreille, 1804}

\section{Porcellio dilatatus Brandt, 1831}

Porcellio dilatatus Brandt, 1831: 78, pl. XII, fig. 6. Lemos de Castro, 1971: 5, fig. 11. - Araujo et al., 1996: 126, figs. 41, 42, 66. - Souza-Kury, 1998: 664. - Araujo, 1999a: 254, fig. 25. - Leistikow and Araujo, 1999: 33. - Zimmermann et al., 2015a: 3, fig. 2, Tabs. 1, 2.

Porcellio scaber - Moreira, 1931: 430.

Distribution. European species introduced all over the world (Schmalfuss, 2003). In Brazil, it is recorded from the states of Minas Gerais, Paraná, Rio de Janeiro, Rio Grande do Sul, São Paulo, and Santa Catarina (Lemos de Castro, 1971; Araujo et al., 1996).

\section{Porcellio laevis Latreille, 1804}

Porcellio laevis Latreille, 1804: 46. - Moreira, 1927: 194. - Camargo, 1954: 123, fig. 2. - Lemos de Castro, 1971: 4, fig. 10 Araujo et al., 1996: 128, figs. 43, 44, 66. - Souza-Kury, 1998: 664. - Araujo, 1999a: 254, fig. 26. - Leistikow and Araujo, 1999: 34. - Zimmermann et al., 2015a: 3, fig. 2, Tabs. 1, 2.

Distribution. Native species from southern Europe and northern Africa, introduced all over the world (Schmalfuss, 2003). In Brazil, it is recorded from the states of Rio de Janeiro, Rio Grande do Sul, Santa Catarina and São Paulo (Lemos de Castro, 1971; Araujo et al., 1996).

\section{Porcellio scaber Latreille, 1804}

Porcellio scaber Latreille, 1804: 45. - Araujo et al., 1996: 125, figs. 39, 40, 66. - Souza-Kury, 1998: 664. 
- Araujo, 1999a: 253, fig. 27. - Leistikow and Wägele, 1999: 34.

nec Porcellio scaber - Moreira, 1931: 430.

Distribution. European species introduced all over the world (Schmalfuss, 2003). In Brazil, it is recorded from the states of Rio Grande do Sul and Santa Catarina (Araujo et al., 1996).

\section{Genus Porcellionides Miers, 1877}

\section{Porcellionides advena (Stuxberg, 1872)}

Porcellio advena Stuxberg, 1972: 4, pl. X.

Porcellionides advena - Van Name, 1936: 247, figs. 139, 140. - Souza-Kury, 1998: 664. - Leistikow and Wägele, 1999: 35. - Schmalfuss, 2003: 209.

nec Metoponorphus chilensis - Budde-Lund, 1885: 191 (not synonym of Porcellionides advena) [=nomen dubium].

Distribution. Endemic to Brazil (Caldas, state of Minas Gerais) (Van Name, 1936).

\section{Porcellionides pruinosus (Brandt, 1833)}

Porcellio pruinosus Brandt, 1833: 19.

Metoponorphus schwencki Moreira, 1927: 195, figs. 4-6. - Moreira, 1931: 430, pl. III, figs. 1-8. - Schwenck, 1927: ?, figs. 7, 8 and 10.

Metoponorthus pruinosus - Andersson, 1960a: 564. - Vilela et al., 1972: 17. - Camargo, 1954: 123, fig. 3. - Lemos de Castro, 1967: 323. - Lemos de Castro, 1972a: 357.

Metoponorthus (Metoponorthus) pruinosus - Lemos de Castro, 1971: 5, fig. 9.

Porcellionionides schwencki - Souza-Kury, 1998: 664.

Porcellionides pruinosus - Araujo et al., 1996: 129, figs. 45-47. - Souza-Kury, 1998: 664. - Leistikow and Wägele, 1999: 35. - Araujo, 1999a: 255, fig. 28. - Schmalfuss, 2003: 212. - Campos-Filho, 2008: 45, fig. 53, Tab. 1. - Appel et al., 2011: 125. - Souza et al., 2013: 72, fig. 2. - Campos-Filho et al., 2014: 412, fig. 40. - Grangeiro et al., 2014: 93, fig. 1a. - Zimmermann et al., 2015a: 3, Tab. 1.

Distribution. Cosmopolitan species of Mediterranean origin (Schmalfuss, 2003). In Brazil, it is considered introduced, recorded from the states of Bahia, Ceará, Espírito Santo, Pará, Piauí, Rio Grande do Sul, and Santa Catarina (Souza-Kury, 1998; Campos-Filho, 2008; Souza et al., 2013; Campos-Filho et al., 2014; Grangeiro et al., 2014).

\section{Porcellionides sexfasciatus} (Budde-Lund, 1885)

Metoponorphus sexfasciatus Budde-Lund, 1885: 167. Porcellionides sexfasciatus - Zardo and Loyola e Silva, 1988: 791. - Araujo et al., 1996: 130, figs. 47, 48, 67. - Souza-Kury, 1998: 665. - Araujo, 1999a: 255, fig. 29. - Leistikow and Wägele, 1999: 35. - Schmalfuss, 2003: 213.

Distribution. Native to the western Mediterranean and introduced all over the world (Schmalfuss, 2003). In Brazil, it is recorded from the states of Paraná, Rio Grande do Sul, and Santa Catarina (Zardo and Loyola e Silva, 1988; Araujo et al., 1996).

\section{Family Armadillidiidae Brandt, 1833}

\section{Genus Armadillidium Brandt, 1831}

\section{Armadillidium nasatum Budde-Lund, 1885}

Armadillidium nasatum Budde-Lund, 1885: 51. Araujo et al., 1996: 136, figs. 59-63, 68. - Souza-Kury, 1998: 654. - Araujo, 1999a: 253, fig. 24. - Leistikow and Wägele, 1999: 43. - Zimmermann et al. 2015a: 3, fig. 2, Tab. 1.

Distribution. European species introduced to North and South Americas (Schamlfuss, 2003). In Brazil, it is recorded from the state of Rio Grande do Sul (Araujo et al., 1996; Zimmermann et al., 2015b).

\section{Armadillidium vulgare (Latreille, 1804)}

Armadillo vulgaris Latreille, 1804: 48.

Armadillidium vulgare - Moreira, 1931: 432. Camargo, 1954: 122, fig. 1. - Lemos de Castro, 1971: 4, fig. 14. - Lenko, 1971: 8. - Vilela et al., 1972: 15. Araujo et al., 1996: 133, figs. 54-58, 68. - Souza-Kury, 1998: 654. - Araujo, 1999a: 252, fig. 23. - Leistikow and Wägele, 1999: 43. - Schmalfuss, 2003: 38. - 
Appel et al., 2011: 124, figs. 1B, 2D-F. - CamposFilho et al., 2014: 412, fig. 40. - Zimmermann et al., 2015a: 3, fig. 2, Tabs. 1, 2.

Distribution. Mediterranean species introduced all over the world (Schmalfuss, 2003). In Brazil, it is recorded from the states of Bahia, Minas Gerais, Paraíba, Rio de Janeiro, Rio Grande do Sul, São Paulo, and Santa Catarina (Souza-Kury, 1998; Zimmermann et al., 2015a).

\section{Incertae sedis}

\section{Stymphalus dilatatus (Perty, 1834)}

Ligia dilatata Perty, 1834: 212, pl. XL, fig. 14.

Stymphalus dilatatus - Budde-Lund, 1879: 9. Budde-Lund, 1885: 271. - Van Name, 1936: 66, fig. 21. - Souza-Kury, 1998: 658. - Leistikow and Wägele, 1999: 3. - Schmalfuss, 2003: 251.

Distribution. Dubious species recorded from the state of Bahia (see Van Name, 1936). Based on the distribution of Ligia exotica provided by Van Name (1936), this species probably corresponds to juvenile specimens of Ligia exotica.

\section{Nomina dubia}

\section{Chaetophiloscia walkeri (Pearse, 1915)}

Philoscia walkeri Pearse, 1915: 541, fig. 4. Leistikow, 2001c: 48.

Chaetophiloscia walkeri - Lemos de Castro, 1967: 319. - Souza-Kury, 1998: 661. - Leistikow and Wägele, 1999: 15. - Schmalfuss, 2003: 70.

Remarks. Species originally described from San Lorenzo, Sierra Nevada de Santa Marta, Colombia, by Pearse (1915). Lemos de Castro (1967) placed this species into the genus Chaetophiloscia based on the dorsal colour of the specimens from the state of Pará (Acará and Belém). As mentioned by Leistikow (2001c), Lemos de Castro did not examine the type material of the species and his recognition was based in Pearse's description; therefore, the author considered this species as a nomen dubium. Taking into account the current distribution of C. walkeri and the biogeography history of the South American Amazon (see Morrone, 2014; Dagosta and de Pinna, 2017), most probably this species belong to a different taxonomic entitiy.

Distribution. State of Pará (Lemos de Castro, 1967).

Circoniscus apeuensis (Lemos de Castro, 1967)

Parsphaeroniscus apeuensis Lemos de Castro, 1967: 325. - Lemos de Castro, 1970e: 41, figs. 1-6. - SouzaKury, 1998: 667.

Circoniscus apeuensis - Leistikow and Wägele, 1999: 37. - Schmalfuss, 2003: 71, 89. - Schmidt, 2007: 89.

Remarks. Schmidt (2007), in the revision of the Neotropical Scleropactidae, considered this species as a nomen dubium because the type material was not present in the collection of the Museu Nacional do Rio de Janeiro where Lemos de Castro used to deposited his material.

Distribution. State of Pará (Lemos de Castro, 1967).

\section{Nomem nudum}

\section{Trichorhina incerta Lemos de Castro, 1972}

Trichorhina incerta Lemos da Castro, 1972a: 357.

Remarks. Lemos de Castro (1972a) mentioned the new species Trichorhina incerta from Sueste Island, Abrolhos Archipelago. However, this species has never been described, and according to the ICZN the name of this species should be considered as a nomen nudum.

Distribution. This species was recorded from Sueste Island, Abrolhos Archipelagous, state of Bahia (Lemos de Castro, 1972a).

\section{General Remarks}

In this paper, we recognized 189 valid species from Brazil, plus one incertae sedis Stymphalus dilatatus, two nomina dubia, Chaetophiloscia walkeri and Circoniscus apeuensis, and one nomen nudum, Trichorhina incerta. Moreover, 135 species are considered endemic to Brazil and 22 are recorded from other countries 
in the Americas, 20 are introduced, and 12 have circumtropical or pantropical distributions.

Our knowledge about the total number of oniscidean species present in Brazil is still far from complete. Brazil is one of the largest countries in the world ( $c a$. 8.5 million $\mathrm{km}^{2}$ ), with a wide variety of ecosystems (MMA, 1998; Mittermeier et al., 2005), most of them designated for priority conservation (Myers et al., 2000). However, as mentioned by CamposFilho et al. (2014), the taxonomic impediment is the major problem to access the diversity of the Brazilian Oniscidea (see also Wheeler et al., 2004).

In the last years, many studies have attempted to access this biodiversity (e.g., Trajano, 2000; Bichuette and Trajano, 2005; Fišer et al., 2013; Silva and Ferreira, 2015 ; 2016). However, most of these studies were performed in the Southeast- and Southern Atlantic Forest regions. More investigations are necessary in other Brazilian regions, especially in the Amazon region, to have a better understanding about the diversity and relationships of the group along the Brazilian territory.

Lastly, it is important to mention that the access to biodiversity constitutes one of the first steps to achieve further investigations in other fields of science (Rull, 2011). Considering that many ecosystems have been suffering from intense alterations due to habitat loss caused by urban expansions, fragmentation or climate changes, the knowledge about the diversity provides subsidies for conservation or management plan strategies (Myers et al., 2000; Mittermeier et al., 2005).

\section{ACKNOWLEDGMENTS}

We are greatful to the associate editor S. Taiti and the anonymous reviewer for their suggestions to improve this catalogue; to CAPES (Coordenação de Aperfeiçoamento de Pessoal de Ensino Superior) for the postdoctoral fellowship granted to ISC-F (CAPES/ PNPD/UFCG/CTRN/PPGRN/201713705-5).

\section{References}

Almerão, M.P.; Fagundes, N.J.R.; Araujo, P.B.; Verne, S.; Grandjean, F.; Bouchon, D. and Araújo, A.M. 2012. First record of Wolbachia in South American terrestrial isopods: prevalence and diversity in two species of Balloniscus (Crustacea, Oniscidea). Genetics and Molecular Biology, 35: 980-989.
Almerão, M.P.; Mendonça Jr, M.S.; Quadros, A.F.; Pedó, E.; Silva, L.G.R. and Araujo P.B. 2006. Terrestrial isopod diversity in the subtropical Neotropics: Itapuã State Park, southern Brazil. Iheringia, Série Zoologia, 96: 473-477.

Andersson, A. 1960a. South American terrestrial isopods in the collection of the Swedish State Museum of Natural History. Arkiv för Zoologi, 12: 537-570.

Andersson, $\AA$. $1960 \mathrm{~b}$. A case of intersexuality in Benthana longicornis Verhoeff (Oniscidae). Arkiv för Zoologi, 12: 415-419.

Angarten, N.B.O.; Ramos, A.M.; Anastácio, E.M.F. and Tagliari, P.D. 2017. Caracterização da fauna de invertebrados em cavidades naturais no âmbito do licenciamento ambiental da ferrovia de integração oeste-leste. p. 9-21. In: M.A. Rasteiro; C.M. Teixeira-Silva and S.G. Lacerda (eds), Anais do 34 Congresso Brasileiro de Espeleologia. Campinas, SBE. Available at: http://www.cavernas.org.br/anais34cbe/34cbe_009-021. pdf. Accessed on: 4 Jun 2018.

Appel, C.; Quadros, A.F. and Araujo P.B. 2011. Marsupial extension in terrestrial isopods (Crustacea, Isopoda, Oniscidea). Nauplius, 19: 123-128.

Araujo, P.B. 1999a. Subordem Oniscidea (isópodos terrestres, "tatuzinhos").p. 237-256. In: L. Buckup and G. Bond-Buckup (eds), Os crustáceos do Rio Grande do Sul. Porto Alegre, Ed. Universidade/UFRGS.

Araujo, P.B. 1999b. Two new species of Alboscia Schultz, 1995 from Rio Grande do Sul, Brazil (Isopoda, Oniscidea, Philosciidae). Crustaceana, 72: 487-496.

Araujo, P.B. and Almerão, M.P. 2007. Nova espécie de Trichorhina (Isopoda, Oniscidea, Plathyarthridae) do Brasil. Iheringia, Série Zoologia, 97: 219-222.

Araujo, P.B. and Bond-Buckup, G. 2004. Growth curve of Atlantoscia floridana (Van Name) (Crustacea, Isopoda, Philosciidae) from a Brazilian Restinga Forest. Revista brasileira de Zoologia, 21: 1-8.

Araujo, P.B. and Bond-Buckup, G. 2005. Population structure and reproductive biology of Atlantoscia floridana (Van Name, 1940) (Crustacea, Isopoda, Oniscidea) in southern Brazil. Acta Oecologica, 28: 289-298.

Araujo, P.B. and Buckup, L. 1994a. Two new species of terrestrial Isopoda from southern Brazil (Crustacea, Isopoda, Oniscidea). Spixiana, 17: 269-274.

Araujo, P.B. and Buckup, L. 1994b. Nova espécie de Trichorhina Budde-Lund, 1908 (Crustacea, Isopoda, Platyarthridae) do sul do Brasil. Iheringia, Série Zoologia, 77: 129-134.

Araujo, P.B. and Buckup, L. 1996a. Novos registros e uma espécie nova de Trichorhina Budde-Lund (Isopoda, Oniscidea, Platyarthridae) do Sul do Brasil. Revista brasileira de Zoologia, 13: 799-810.

Araujo, P.B. and Buckup, L. 1996b. Ocorrência de Nagurus Holthuis, 1949 (Isopoda, Trachelipodidae) no Sul do Brasil. Nauplius, 4: 161-163.

Araujo, P.B. and Bueno, A. 1998. Novos registros de isópodos terrestres do sul do Brasil: Porcellionidae e Trichoniscidae (Crustacea, Oniscidea). Nauplius, 6: 185-186.

Araujo, P.B. and Leistikow, A. 1999. Philosciids with pleopodal lungs from Brazil, with description of a new species (Crustacea, Isopoda). Contributions to Zoology, 68: 109-141. 
Araujo, P.B. and Lopes, E.R. 2003. Three new species of Benthana Budde-Lund (Isopoda, 'Philosciidae') from Brazil. Journal of Natural History, 37: 2425-2439.

Araujo, P.B. and Quadros, A.F. 2005. A new species of Alboscia Schultz, 1995 (Crustacea: Isopoda: Oniscidea: Philosciidae) from Brazil. Zootaxa, 1018: 55-60.

Araujo, P.B. and Taiti, S. 2007. Terrestrial isopods (Crustacea, Oniscidea) from Rocas Atoll, northeastern, Brazil. Arquivos do Museu Nacional, 65: 347-355.

Araujo, P.B. and Zardo, C.M.L. 1995. Uma nova espécie de Balloniscus Budde-Lund (Crustacea, Isopoda, Balloniscidae) do Sul do Brasil. Revista brasileira de Zoologia, 12: 785-790.

Araujo, P.B.; Augusto, M.M. and Bond-Buckup, G. 2004a. Postmarsupial development of Atlantoscia floridana (Van Name, 1940) (Crustacea, Isopoda, Oniscidea): the manca stages. Journal of Natural History, 38: 951-965.

Araujo, P.B.; Buckup, L. and Bond-Buckup, G. 1996. Isópodos terrestres (Crustacea, Oniscidea) de Santa Catarina e Rio Grande do Sul, Brasil. Iheringia, Série Zoologia, 81: 111-134.

Araujo, P.B.; Quadros, A.F.; Augusto, M.M. and Bond-Buckup, G. 2004b. Postmarsupial development of Atlantoscia floridana (van Name, 1940) (Crustacea, Isopoda, Oniscidea): sexual differentiation and size at onset of sexual maturity. Invertebrate Reproduction and Development, 45: 221-230.

Arcangeli, A. 1929. Isopodi terrestri raccolti in Cuba dal Prof. F. Silvestri. Bollettino del Laboratorio di Zoologia Generale e Agraria del Regio Istituto Superiore Agrario di Portici, 23: 129-148.

Arcangeli, A. 1930. Contributo alla conoscenza del "Microgenton" di Costa Rica. I. Isopodi terrestri. Bollettino del Laboratorio di Zoologia Generale e Agraria della R. Scuola Superiore d'Agricoltura in Portici, 25: 1-29.

Arcangeli, A. 1931. Circoniscus bezzii Arc., nuova specie di isopodo terrestre del Brasile. Bollettino di Zoologia, 11: 115-122.

Arcangeli, A. 1934. Note di revisione sulla famiglia Armadillidae. Bollettino dei Musei di Zoologia ed Anatomia Comparata dela Reale Università di Torino, 44: 83-119.

Arcangeli, A. 1936. Un genere e due specie nuovi di isopodi terrestri del Brasile. Archivio Zoologico Italiano, 23: 201-208.

Arcangeli, A. 1957. I generi Diploexochus, Venezillo, Paramardillo [sic] (crostacei isopodi terrestri). Bollettino dell'Istituto e Museo di Zoologia dell'Università di Torino, 5: 101-142.

Audouin, J.V. 1826. Explication sommaire des planches de Crustace's de l'Égypte et de la Syrie, publiées par JulesCésar Savigny, Membre de l'Institut, offrant un exposé des caractères naturels des genres, avec la distinction des espèces. p. 77-98. In: Description de l'Égypte, ou recueil des observations et des recherches qui ont été faites en Égypte pendant l'expédition de l'Armée française, publié par les ordres de sa Majesté l'Empereur Napoléon le Grand. Histoire Naturelle 1 ( $4^{\mathrm{e}}$ partie).

Barnard, K. 1932. Contribution to the fauna of South Africa. 11. Terrestrial Isopoda. Annals of the South African Museum, 30: 179-388.

Bastos-Pereira, R.; Souza, L.A. and Ferreira, R.L. 2017. A new amphibious troglobitic styloniscid from Brazil (Isopoda, Oniscidea, Synocheta). Zootaxa, 4294: 292-300.

Bichuette, M.E. and Trajano, E. 2005. A new cave species of Rhamdia Bleeker, 1858 (Siluriformes: Heptapteridae) from
Serra do Ramalho, northeastern Brazil, with notes on ecology and behavior. Neotropical Ichthyology, 3: 587-595.

Boyko, C.B. 1997. Catalog of recent type specimens in the Department of Invertebrates, American Museum of Natural History. IV. Crustacea: Isopoda. American Museum Novitates, 3217: 1-39.

Brandt, J.F. 1831. Isopoda. Gleichfüßler. p. 70-84, pls 12-13. In: J.F. Brandt and J.C.T. Ratzeburg (eds), Medizinische Zoologie oder getreue Darstellung und Beschreibung der Tiere die in der Arzneimittellehre in Betracht kommen, in systematischer Folge herausgegeben. Vol. 2. Isopoda. Berlin.

Brandt, J.F. 1833. Conspectus Monographiae Crustaceorum Oniscodorum Latreillii. Byulleten Moskovskogo Obshchestva Ispŷtatelě Prirodŷ, 6: 171-193, pl. 4.

Budde-Lund, G. 1879. Prospectus generum specierumque Crustaceorum Isopodum Terrestrium. Copenhaguen, Imprimerie de Jørgensen \& Knudtzon, pp. 10.

Budde-Lund, G. 1880. Isopoda [Oniscidea]. In: Meinert, F. (ed), Crustacea Isopoda, Amphipoda et Decapoda Daniae. Naturhistorisk Tidsskrift, 12: 467-470.

Budde-Lund, G. 1885. Crustacea Isopoda Terrestria per Familias et Genera et Species Descripta. Copenhagen, Nielsen \& Lydiche. 319p.

Budde-Lund, G. 1893. Landisopoder fra Venezuela, indsamlede af Dr. Fr. Meinert. Entomologiske Meddelelser, 4: 111-129.

Budde-Lund, G. 1899. Eubelum. p. 67-97. In: A revision of Crustacea Isopoda terrestria, with additions and illustrations. Copenhagen, H. Hagerup.

Budde-Lund, G. 1902. A list of terrestrial isopods. In: Lanchester, W. (ed), On the Crustacea collected during the Skeat Expedition to the Malay Peninsula. Proceedings of the Zoological Society of London, 1902: 379-381.

Budde-Lund, G. 1904. A revision of Crustacea Isopoda terrestria, with additions and illustrations. pt. 1 Eubelum, pt. 2 Spherilloninae, pt. 3 Armadillo. p. 33-144, pls. 6-10. Copenhagen, H. Hagerup.

Budde-Lund, G. 1908. Isopoda von Madagaskar und Ostafrika mit Diagnosen verwandter Arten. p. 265-308, pls. 12-18. In: Voeltzkow, A. (ed), Reise in Ostafrika in den Jahren 19031905. Vol. 2. Stuttgart, Wissenschaftliche Ergebnisse.

Budde-Lund, G. 1913. Terrestrial Isopoda, particularly considered in relation to the distribution of the southern Indo-Pacific species. Transactions of the Linnean Society of London, $2^{\text {nd }}$ Series, 15: 367-394.

Bueno, A.A.P.; Araujo, P.B. and Santos, S. 2018. Ludwig Buckup's academic life and his contribution to Carcinology. Nauplius, 26: e2018007.

Camargo, O.R. 1954. Isópodos terrestres do Rio Grande do Sul. Revista Agronômica, Série I 209-211: 122-128.

Camargo, O.R. 1955. Tatuzinhos (Crustacea, Isopoda) do Rio Grande do Sul. Porto Alegre, Secretaria de Estado dos Negócios da Agricultura, Indústria e Comércio. 9p.

Campos-Filho, I.S. 2008. Oniscidea (Crustacea, Isopoda) de Orós, CE. URCA - Universidade Regional do Cariri, Crato. Graduation Thesis, 62 pp. [Unpublished]

Campos-Filho, I.S. and Araujo, P.B. 2011 a. New species of Benthana Budde-Lund, 1908 (Crustacea: Oniscidea: Philosciidae) from Paraná, Brazil. Zootaxa, 2765: 38-46. 
Campos-Filho, I.S. and Araujo, P.B. 2011b. Two new troglobitic species of Scleropactidae (Crustacea: Isopoda: Oniscidea) from Pará, Brazil. Nauplius, 19: 27-39.

Campos-Filho, I.S.; Contreira, S.G. and Lopes-Leitzke, E.R. 2012. A new species of Atlantoscia Ferrara \& Taiti, 1981 (Oniscidea: Philosciidae) from Rio Grande do Sul, Brazil. Nauplius, 20: 138-144.

Campos-Filho, I.S.; Araujo, P.B.; Bichuette, M.E.; Trajano, E. and Taiti, S. 2014. Terrestrial isopods (Crustacea: Isopoda: Oniscidea) from Brazilian caves. Zoological Journal of the Linnean Society, 172: 360-425.

Campos-Filho, I.S.; Bichuette, M.E. and Taiti, S. 2016. Three new species of terrestrial isopods (Crustacea, Isopoda, Oniscidea) from Brazilian caves. Nauplius, 24: e2016001.

Campos-Filho, I.S.; Bichuette, M.E.; Araujo, P.B. and Taiti, S. 2017a. Description of a new species of Cylindroniscus Arcangeli, 1929 (Isopoda: Oniscidea) from Brazil, with considerations on the family placement of the genus. NorthWestern Journal of Zoology, 13(2): e161305.

Campos-Filho, I.S.; Bichuette, M.E.; Montesanto, G.; Araujo, P.B. and Taiti, S. 2017b. The first troglobiotic species of the family Pudeoniscidae (Crustacea, Isopoda, Oniscidea), with descriptions of a new genus and two new species. Subterranean Biology, 23: 69-84.

Campos-Filho, I.S.; Cardoso, G.M. and Aguiar, J.O. 2018a. New species and first record of Alloniscus Dana, 1854 (Isopoda, Oniscidae, Alloniscidae) from Brazil. Nauplius, 26: e2018014.

Campos-Filho, I.S.; Costa, S.L.N. and Araujo, P.B. 2013a. Two new species of Benthana Budde-Lund, 1908 (Crustacea: Isopoda: Philosciidae) from Brazil. Tropical Zoology, 26(1): 1-14.

Campos-Filho, I.S.; Lisboa, J.T. and Araujo, P.B. 2013b. Review of Atlantoscia Ferrara \& Taiti, 1981 (Crustacea: Isopoda: Oniscidea: Philosciidae) with new records and new species. Organisms, Diversity \& Evolution, 13: 463-483.

Campos-Filho, I.S.; Lisboa, J.T. and Cardoso, G.M. 2018b. A new genus and two new species of Pudeoniscidae Lemos de Castro 1973 (Crustacea: Isopoda: Oniscidea) from Brazil. Journal of Natural History, 52: 457-482.

Campos-Filho, I.S.; Mise, K.M. and Sessegolo, G.C. 2015a. A new species of Trichorhina Budde-Lund, 1908 (Isopoda: Oniscidea: Platyarthridae) from Paraná caves, southern Brazil. Nauplius, 23: 112-119.

Campos-Filho, I.S.; Montesanto, G.; Araujo, P.B. and Taiti, S. 2017c. New species and new records of terrestrial isopods (Crustacea, Isopoda, Oniscidea) from Brazil. Iheringia, Série Zoologia, 107: e2017034.

Campos-Filho, I.S.; Taiti, S. and Araujo, P.B. 2015b. Taxonomic revision of the genus Benthana Budde-Lund, 1908 (Isopoda: Oniscidea: Philosciidae). Zootaxa, 4022: 1-73.

Cardoso, G.M.; Araujo, P.B. and Bichuette, M.E. 2017. Two new species of Neotroponiscus Arcangeli, 1936 (Crustacea, Isopoda, Oniscidea) from Brazilian caves. Studies on Neotropical Fauna and Environment, 52: 122-130.

Cardoso, G.M.; Campos-Filho, I.S. and Araujo, P.B. 2016. The genus Dubioniscus Vandel, 1963 (Oniscidea, Dubioniscidae) with descriptions of two new species from Brazil, Tropical Zoology, 29: 111-133.

Cardoso, G.M.; Campos-Filho, I.S. and Araujo, P.B. 2018. Taxonomic revision of Brasiloniscus (Oniscidea,
Pudeoniscidae) with description of a new species. European Journal of Taxonomy, 434: 1-16.

Carpio-Díaz, Y.M.; López-Orozco, C.M.; Herrera-Medina, Y.; Navas-S., G.R. and Bermúdez, A. 2016. Primer registro de Tylos niveus y nuevo reporte de Porcellionides pruinosus (Oniscidea: Tylidae y Porcellionidae) para Colombia. Revista de la Academia Colombiana de Ciencias Exactas, Físicas y Naturales, 40: 433-437.

Cavalcanti, L.F. 2017. Dados secundários de espécies classificadas como troglóbias e troglomórficas para o projeto áreas prioritárias para a conservação do patrimônio espeleológico brasileiro. p. 43-66. In: M.A. Rasteiro; C.M. Teixeira-Silva and S.G. Lacerda (eds), Anais do 34 ${ }^{\circ}$ Congresso Brasileiro de Espeleologia. Campinas: SBE. Available at: http://www. cavernas.org.br/anais34cbe/34cbe_043-066.pdf. Accessed on 4 Jun 2018.

Chilton, C. 1901. The terrestrial Isopoda of New Zealand. Transactions of the Linnean Society of London, Zoology, 8: 99-152, pls. 11-16.

Collinge, W.E. 1914. Terrestrial Isopoda. In: Zoological results of the Abor Expedition. Records of the Indian Museum, 8: 465-469, pls. 31-33.

Collinge, W.E. 1915. Description of a new genus and species of terrestrial Isopoda from British Guiana. Journal of the Linnean Society, Zoology, 32: 509-511, pl. 50.

Costa, L.P. 2003. The historical bridge between the Amazon and the Atlantic Forest of Brazil: a study of molecular phylogeography with small mammals. Journal of Biogeography, 30: 71-86.

Costa, S.L.N.; Campos-Filho, I.S. and Araujo, P.B. 2014. New species and new records of Benthana Budde-Lund, 1908 (Isopoda: Oniscidea: Philosciidae) from southern Brazil. Papéis Avulsos de Zoologia, 54: 169-176.

Dagosta, F. C. P. and de Pinna, M. 2017. Biogeography of Amazonian fishes: deconstructing river basins as biogeographic units. Neotropical Ichthyology, 15: e170034.

Dana, J.D. 1852. On the classification of the Crustacea Choristopoda or Tetradecapoda. The American Journal of Science and Arts, 14: 297-316.

Dana, J.D. 1853. Crustacea, Part II. Isopoda. United States exploring expedition during the years 1838, 1839, 1840, 1841, 1842 under the command of Charles Wilkens, U.S.N., Vol. 14, p. 696-805, pls. 46-53. Philadelphia, C. Sherman.

Dana, J.D. 1854. Catalogue and description of Crustacea collected in California by Dr. John L. Le Conte. Proceedings of the Academy of Natural Sciences of Philadelphia, 7: 175-177.

Dollfus, A. 1889. Sur quelques isopodes du Musée de Leyde. Notes from the Leiden Museum, 11: 91-94, pl. 5.

Dollfus, A. 1896. On West Indian terrestrial isopod crustaceans. Proceedings of the Zoological Society of London, 1896: 388-400.

Dollfus, A. 1897. Viaggio del dott. A. Borelli nel Chaco Boliviano e nella Repubblica Argentina. VI. Isopodes terrestres. Bollettino dei Musei di Zoologia ed Anatomia Comparata della Regia Università di Torino, 12(289): 1-4.

Dollfus, A. 1898. Isopodes terrestres des Indes néerlandaises. p. 357-381, pls. 13-15. In: Weber, M. (ed), Zoologische Ergebnisse einer Reise in Niederländisch Ost-Indien. Leiden, E.J. Brill. 
Fabricius, J.C. 1798. Supplementum entomologiae systematicae. Hafniae, CG Proft \& Storch, p. 296-306.

Fernandes, C.S.; Batalha, M.A. and Bichuette, M.E. 2016. Does the cave environment reduce functional diversity? PLoS ONE, 11: e0151958.

Fernandes, C.S.; Campos-Filho, I.S. and Bichuette, M.E. 2018. Cylindroniscus platoi (Isopoda: Oniscidea: Styloniscidae), a new cave-dwelling species from Lagoa Santa Karst, Southeasthern Brazil. Zootaxa, 4461: 411-420.

Ferrara, F. and Taiti, S. 1981. Terrestrials isopods from Ascension Island. Monitore Zoologico Italiano, 13(Suppl. 14): 189-198.

Ferrara, F. and Taiti, S. 1982. Isopodi terrestri delle Isole Andamane. Bollettino del Museo Civico di Storia Naturale di Verona, 8: 459-492.

Ferrara, F. and Taiti, S. 1990. Two new species of Reductoniscus (Crustacea, Oniscidea, Armadillidae) from New Guinea. Revue Suisse de Zoologie, 97: 489-497.

Fišer, C.; Zagmajster, M. and Ferreira, R.L. 2013. Two new Amphipod families recorded in South America shed light on an old biogeographical enigma. Systematics and Biodiversity, 11: 117-139.

Furlan, S.A. 1996. Indicadores biogeográficos em fragmentos de Mata Atlântica insular e continental e suas possíveis implicações paleoambientais. Revista do Departamento de Geografia, 10: 13-28.

Gallão, J.E. and Bichuette, M.E. 2018. Brazilian obligatory subterranean fauna and threats to the hypogean environment. ZooKeys, 746: 1-23.

Gerstäcker, A. 1873. Isopoda, p. 525-528, pl. 2. In: Von der Decken (ed), Reisen in Ostafrika in den Jahren 1859-1865. Ordo III. C.F. Leipzig und Heidelber, Winter'sche Verlagshandlung.

Giambiagi de Calabrese, D. 1931. Oniscoideos del Rio de la Plata (primera parte). Anales del Museo Nacional de Buenos Aires, Historia Natural, 36: 417-429.

Giambiagi de Calabrese, D. 1939. Contribución al estudio de los isopodos terrestres argentinos. Physis, 17: 633-644, pls. I-X.

Gräeve, W. 1914. Die Trichoniscinen der Umgebung von Bonn. Zoologische Jahrbücher, Abteilung für Systematik, Ökologie und Geographie der Tiere, 36: 199-228, pls. 4-6.

Grangeiro, D.C. and Christoffersen, M.L. 2010. A new species of Androdeloscia (Isopoda: Philosciidae) from the Brazilian Amazon. Revista Nordestina de Biologia, 19(2): 77-93.

Grangeiro, D.C.; Borges, N.R.S. and Moura, G.I.B.S.C. 2014. Primeiro registro de crustáceos terrestres (Isopoda, Oniscidea) para o Piauí, Brasil. p. 89-101. In: D.C. Grangeiro; G.S. Azar and W.R.L.S. Pessoa (eds), Pesquisa do Semiárido Piauiense. Curitiba, Editora CRV.

Grangeiro, D.C.; Souza, L.A. and Christoffersen, M.L. 2017. New species of Xiphoniscus and new record of Androdeloscia escalonai (Isopoda, Scutocoxifera, Oniscidea, Philosciidae) from Brazilian Amazon. Zootaxa, 4350: 374-384.

Green, A. J. A. 1971. Styloniscidae (Isopoda, Oniscoidea) from Tasmania and New Zealand. Papers and Proceedings of the Royal Society of Tasmania, 105: 59-74.

Gregory, S.J. 2014. Woodlice (Isopoda: Oniscidea) from the Eden Project, Cornwall, with descriptions of species new to Britain and poorly known British species. Bulletin of the British Myriapod and Isopod Group, 27: 3-26.
Gruner, H.E. 1955. Die Gattung Benthana Budde-Lund, 1908 (Isopoda, Oniscoidea). Zoologische Jahrbücher, Abteilung für Systematik, Ökologie und Geographie der Tiere, 83: 441-452.

Hatch, M. 1947. The Chelifera and Isopoda of Washington and adjacent regions. University of Washington Publications in Biology, 10: 174-205.

Holthuis, L.B. 1947. On a small collection of isopod Crustacea from the greenhouses of the Royal Botanic Gardens, Kew. Annals and Magazine of Natural History, Series 11, 13: 122-137.

Holthuis, L.B. 1949. The Isopoda and Tanaidacea of the Netherland, including the description of a new species of Limnoria. Zoologische Mededelingen, 30: 163-190.

Hornung, E. 2011. Evolutionary adaptation of oniscidean isopods to terrestrial life: structure, physiology and behavior. Terrestrial Arthropod Reviews, 4: 95-130.

Hurtado, L.A.; Lee, E.J.; Mateos, M. and Taiti, S. 2014. Global diversification at the harsh sea-land interface: mitochondrial phylogeny of the supralittoral isopod genus Tylos (Tylidae, Oniscidea). PLoS ONE, 9: e94081.

Jackson, H.G. 1926. Woodlice from Spain and Portugal, with an account of Benthana, a sub-genus of Philoscia. Proceedings of the Zoological Society of London, 1926: 183-201, pls. I-VIII.

Jass, P.J. and Klausmeier, B.R. 2006. Transborder associations of terrestrial isopods (Crustacea, Isopoda, Oniscidea) of Mexico and the United States. Western North American Naturalist, 66: $132-134$.

Javidkar, M.; Cooper, S.J.B.; King, R.A.; Humphreys, W.F. and Austin, A. 2015. Molecular phylogenetic analyses reveal a new southern hemisphere oniscidean family (Crustacea: Isopoda) with a unique water transport system. Invertebrate Systematics, 29: 554-577.

Jeppesen, P. 2000. Catalogue of terrestrial isopod taxa and type material described by Gustav Budde-Lund (Crustacea: Isopoda). Steenstrupia, 25: 221-265.

Kenne, D.C. and Araujo, P.B. 2015. Balloniscus glaber (Crustacea, Isopoda, Balloniscidae), a habitat specialist species in a disturbed area of Brazil. Iheringia, Série Zoologia, 105: 430-438.

Kesselyák, A. 1930. Über Isopoden. Zoologischer Anzeiger, 91: 50-66.

Kinahan, J. 1857. Analysis of certain allied genera of terrestrial isopods; with description of a new genus, and a detailed list of the British species of Ligia, Philougria, Philoscia, Porcellio, Oniscus and Armadillium [sic]. Natural History Review, 4: 258-282, pls. 19-22.

Kraepelin, K. 1901. Über die durch den Schiffsverkehr in Hamburg eingeschleppten Tiere. Mitteilungen aus dem Naturhistorischen Museum in Hamburg, 18: 183-209.

Kwon, D.H. and Taiti, S. 1993. Terrestrial Isopoda (Crustacea) from southern China, Macao and Honk Kong. Stuttgarter Beiträge zur Naturkunde, Serie A, 490: 1-83.

Latreille, A. 1802. Histoire naturelle, générale et particulière des crustacés et des insects. Tome III. Famille Seconde. Cloportides. Paris, L'Imprimeria de F. Dufart, p. 42-43.

Latreille, P.A. 1804. Histoire naturelle, générale et particulière des Crustacés et des Insectes. p. 1-413, pls 58-66. In: C.S. Sonnini (ed), Histoire naturelle, générale et particulière, des Crustacés et Insectes: ouvrage faisant suite aux oeuvres 
de Leclerc de Buffon, et partie du Cours complet d'Histoire naturelle. Vol. VII. Paris, L'Imprimeria de F. Dufart.

Leach, W.E. 1814. Crustaceology. p. 406. In: D. Brewster (ed), The Edinburg Encyclopaedia. Vol. VII. Edinburg: William Blackwood, John Waugh, John Murray, Baldwin \& Cradock, J.M. Richardson and other proprietors.

Ledo, R.M.D. and Colli, G.R. 2017. The historical connections between the Amazon and the Atlantic Forest revisited. Journal of Biogeography, 44: 2551-2563.

Leistikow, A. 1999. Androdeloscia gen. n., a new genus of South American terrestrial isopods with description of 13 new species (Crustacea: Oniscidea: "Philosciidae"). Revue Suisse de Zoologie, 106: 813-904.

Leistikow, A. 2000. A new genus of Oniscidea from South America and a phylogenetic analysis of related genera (Crustacea: Isopoda: Philosciidae). Contributions to Zoology, 69: 179-196.

Leistikow, A. 2001a. Designation of a type species for the genus Prosekia, gen. nov. from South America (Crustacea, Isopoda, Oniscidea). Spixiana, 24: 111-121.

Leistikow, A. 2001b. Phylogeny and biogeography of South American Crinocheta, traditionally placed in the family "Philosciidae" (Crustacea: Isopoda: Oniscidea). Organisms, Diversity \& Evolution, Electronic Supplement, 4: 1-85.

Leistikow, A. 2001c. New genera of terrestrial isopods (Oniscidea: Philosciidae) from South America, with remarks on some species. p. 19-49. In: B. Kensley and R. Brusca (eds), Isopod Systematics and Evolution. Leiden, Brill. Crustacean Issues, 13.

Leistikow, A. and Araujo, P.B. 2001. Morphology of respiratory organs in South American Oniscidea ("Philosciidae"). p. 329336. In: B. Kensley and R. Brusca (eds), Isopod Systematics and Evolution. Leiden, Brill. Crustacean Issues, 13.

Leistikow, A. and Araujo, P.B. 2006. The systematic position of Benthanoscia longicaudata Lemos de Castro, 1958 (Isopoda: Oniscidea: Crinocheta). Systematics and Biodiversity, 4:243254.

Leistikow, A. and Wägele, J.W. 1999. Checklist of terrestrial isopods of the New World (Crustacea, Isopoda, Oniscidea). Revista brasileira de Zoologia, 16: 1-72.

Lemos de Castro, A. 1952. Sôbre a occorrência do gênero Tylos Latreille no litoral brasileiro (Isopoda, Tylidae). Boletim do Museu Nacional, Nova Serie, Zoologia, 107: 1-9.

Lemos de Castro, A. 1953. Fauna do Distrito Federal, VIII. Sôbre a ocorrência dos Gêneros 'Miktoniscus' e 'Cordioniscus' no Rio de Janeiro. (Isopoda, Trichoniscidae). Anais da Academia Brasileira de Ciência, 25: 527-534.

Lemos de Castro, A. 1955. 'Ischioscia amazonica', uma nova espécie de isopode terrestre do Estado do Amazonas (Isopoda, Oniscidae). Revista Brasileira de Biologia, 15: 51-55.

Lemos de Castro, A. 1958a. On the systematic position of some American species of Philoscia Latreille (Isopoda, Oniscoidea). American Museum Novitates, 13: 10.

Lemos de Castro, A. 1958b. Revisão do gênero Benthana BuddeLund, 1908 (Isopoda, Oniscidae). Arquivos do Museu Nacional, 44: 85-118.

Lemos de Castro, A. 1958c. Benthanoscia longicaudata, a new genus and species of terrestrial isopod of the family Oniscidae (Isopoda, Oniscoidea). American Museum Novitates, 1884: 1-7.
Lemos de Castro, A. 1960. Sôbre as espécies americanas de Phalloniscus Budde-Lund (Isopoda, Oniscidae), com descrição de 4 espécies novas. In: Actas y Trabajos de Primer Congreso Sudamericano de Zoologia, La Plata, vol. 2: 203-211.

Lemos de Castro, A. 1962. Sobre a distribuição geográfica do gênero Halophiloscia Verhoeff. Boletim do Museu Nacional, 238: 1-7.

Lemos de Castro, A. 1964. Trichorhina heterophthalma, nueva espécie de isópodo terrestre cavernícola de Cuba. Poeyana, Seria A, 2: 1-7.

Lemos de Castro, A. 1965. On the systematics of the genus Littorophiloscia Hatch (Isopoda, Oniscidae). Arquivos do Museu Nacional, 53 (1968): 85-98.

Lemos de Castro, A. 1967. Isópodos terrestres da Amazônia Brasileira (Isopoda, Oniscoidea). Atas do Simpósio sôbre a Biota Amazônica, 5: 311-336.

Lemos de Castro, A. 1968. Descrição complementar de "Calycuoniscus goeldii" (Lemos de Castro) (Isopoda terrestria, Oniscidae, Bathytropinae). Revista Brasileira de Biologia, 28: 407-412.

Lemos de Castro, A. 1969. Descrição complementar de Amazoniscus arlei Lemos de Castro (Isopoda Terrestria Eubelidae). Boletim do Museu Nacional, Nova Série, Zoologia, (269): 1-5.

Lemos de Castro, A. 1970a. Consideração sobre o gênero Dubioniscus Vandel, com descrição de uma espécie nova. Boletim do Museu Nacional, 274: 1-6.

Lemos de Castro, A. 1970b. Descrição complementar de Phalloniscus singularis Lemos de Castro (Isopoda terrestria - Oniscidae). Atas da Sociedade de Biologia do Rio de Janeiro, 13: 119-120.

Lemos de Castro, A. 1970c. Isópodos terrestres do gênero Neotroponiscus Arcangeli (Oniscidae - Bathytropinae). Anais da Academia Brasileira de Ciências, 42: 89-95.

Lemos de Castro A. 1970d. Quatro espécies novas de isópodos terrestres do gênero Neotroponiscus Arcangeli (Oniscidae Bathytropinae) do Brasil. Boletim do Museu Nacional, Nova Série, Zoologia, 275: 1-15.

Lemos de Castro, A. 1970e. Descrição complementar de Parsphaeroniscus apeuensis Lemos de Castro (Isopoda terrestria, Eubelidae). Atas da Sociedade de Biologia do Rio de Janeiro, 13: 41-42.

Lemos de Castro, A. 1971. Isópodos terrestres introduzidos no Brasil (Isopoda, Oniscoidea). Boletim do Museu Nacional, 282: 1-14.

Lemos de Castro, A. 1972a. Contribuições ao conhecimento da fauna do Arquipélago de Abrolhos. 3. Isópodos terrestres (Isopoda, Oniscidea). Anais da Academia Brasileira de Ciências, Resumo das Comunicações, 44: 357.

Lemos de Castro, A. 1972b. Considerações sobre o gênero Reductoniscus, com descrição de uma espécie nova (Isopoda, Oniscoidea). Revista Brasileira de Biologia, 32: 347-349.

Lemos de Castro, A. 1973. Pudeoniscidae, família nova, com descrição de um gênero novo e três espécies novas de isópodos terrestres (Isopoda, Oniscoidea). Boletim do Museu Nacional, Nova Série, Zoologia, 287: 1-10, pls. 1-5.

Lemos de Castro, A. 1976. Considerações sobre a sinonímia e a distribuição geográfica de Balloniscus sellowii (Brandt, 1833) 
(Isopoda, Balloniscidae). Revista Brasileira de Biologia, 36: 391-396.

Lemos de Castro, A. 1984a. Uma nova espécie de Prosekia (Philosciidae, Isopoda) de uma floresta inundável (Igapó) na Amazonia central. Amazoniana, 8: 441-445.

Lemos de Castro, A. 1984b. Microsphaeroniscus, gênero novo de isópode terrestre volvacional [= Bisilvestria Arcangeli, 1929], com descrição de cinco espécies novas (Isopoda, Oniscoidea). Boletim do Museu Nacional, Nova Serie, Zoologia, 308: 1-5, pls. 1-4.

Lemos de Castro, A. 1985a. Considerações sobre Atlantoscia alceui Ferrara \& Taiti, 1981 (Isopoda, Oniscoidea, Philosciidae). Revista Brasileira de Biologia, 45: 417-422.

Lemos de Castro, A. 1985b. Duas espécies novas brasileiras de Benthana Budde-Lund, 1908 (Isopoda, Oniscoidea, Philosciidae). Revista Brasileira de Biologia, 45: 241-247.

Lemos de Castro, A. and Souza, L.A. 1986. Três espécies novas de isópodes terretres do gênero Prosekia Vandel da Amazônia Brasileira (Isopoda, Oniscoidea, Philosciidae). Revista Brasileira de Biologia, 46: 429-438.

Lenko, K. 1971. Subsídios para o conhecimento dos isópodos inquilinos de formigas no Brasil (Isopoda, Oniscoidea). Revista Brasileira de Entomologia, 15: 1-10.

Lewis, F. 1998. Oniscidea (Isopoda) from Lord Howe Island. Crustaceana, 71: 743-777.

Lima, I.M.B. 1996a. Uma nova espécie de Prosekia Vandel, 1968 da Amazônia brasileira (Crustacea: Isopoda: Philosciidae). Amazoniana, 14: 101-108.

Lima, I.M.B. 1996b. Uma nova espécie de Circoniscus Pearse, 1917 da região amazônica do Brasil (Crustacea: Isopoda: Scleropactidae). Amazoniana, 14: 91-100.

Lima, M.I. and Serejo, C.S. 1993. A new species of Benthana Budde-Lund from Brazilian caves (Crustacea; Isopoda; Oniscoidea). Proceedings of the Biological Society of Washington, 106: 490-496.

Linnaeus, C. 1758. Systema naturae per regna tria naturae: secundum classes, ordines, genera, species, cum characteribus, differentiis, synonymis, locis. Tomus I. Editio Decima. Holmiae: Impensis Direct, Laurentii Salvii, p. 637.

Lisboa, J.T. Campos-Filho, I.S.; Couto, E.C.G. and Araujo, P.B. 2017. Distribution of terrestrial isopods of the genus Littorophiloscia (Isopoda, Halophilosciidae) along the Brazilian coast. North-Western Journal of Zoology, 13: e167301.

Lisboa, J.T.; Couto, E.C.G.; Santos, P.P.; Delabie, J.H.C. and Araujo, P.B. 2013. Terrestrial isopods (Crustacea: Isopoda: Oniscidea) in termite nests (Blattodea: Termitidae) in a cocoa plantation in Brazil. Biota Neotropica, 13: 393-397.

Lopes, E.R.C. and Araujo, P.B. 2003. New species of Novamundoniscus Schultz (Isopoda, Oniscidea, Dubioniscidae) para o Rio Grande do Sul, Brasil. Revista brasileira de Zoologia, 20: 611-614.

Lopes, E.R.C.; Blasina, J.R.; Dumont, L.F.C. and D’Incao, F. 2006. Biologia reprodutiva de Ligia exotica (Crustacea, Isopoda, Ligiidae) em Rio Grande, Rio Grande do Sul, Brasil. Iheringia, Série Zoologia, 96: 5-12.

Lopes, E.R.C.; Mendonça Jr, M.S.; Bond-Buckup, G. and Araujo, P.B. 2005. Oniscidea diversity across three environments in an altitudinal gradient in northeastern Rio Grande do Sul, Brazil. European Journal of Soil Biology, 41: 99-107.
Lopes-Leitzke, E.R.; Dumont, L.F.C. and D’Incao, F. 2009. Growth of Ligia exotica (Isopoda: Oniscidea: Ligiidae) in two estuarine regions of Patos Lagoon, Rio Grande do Sul, Brazil. Journal of the Marine Biological Association of the United Kingdom, 89: 735-741.

Lopes-Leitzke, E.R.; Macedo, C.W.S.S.; Longaray, D.A. and D'Incao, F. 2011. Natural diet of Ligia exotica (Crustacea, Isopoda, Ligiidae) in two estuarine regions of Patos Lagoon, Rio Grande do Sul, Brazil. Atlântica, 33: 149-160.

López-Orozco, C.M.; Bermúdez, A. And Navas S., G.R. 2014. Primer registro de Ligia baudiniana (Crustacea: Isopoda: Oniscidea) para el Caribe Colombiano. Boletín de Investigaciones Marinas y Costeras, 43: 195-200.

López-Orozco, C.M.; Carpio-Díaz, Y.M.; Suárez, G.R.N. and Campos-Filho, I.S. 2016. A new species and first record of Androdeloscia (Oniscidea: Philosciidae) from Colombia. Studies on Neotropical Fauna and Environment, 52: 18-24.

Magrini, M.J.; Araujo, P.B. and Uehara-Prado, M. 2010. Crustacea, Isopoda, Oniscidea Latreille, 1802: new continent record and distribution extension in Brazil. Checklist, 6: 217-219.

Magrini, M.J.; Freitas, A.V.L. and Uehara-Prado, M. 2011. The effects of four types of anthropogenic disturbances on composition and abundance of terrestrial isopods (Isopoda: Oniscidea). Zoologia, 28: 63-71.

Meinhardt, H.; Quadros, A.F. and Araujo, P.B. 2007. Growth curve of Balloniscus glaber Araujo \& Zardo (Crustacea, Isopoda, Oniscidea) from Parque Estadual de Itapuã, Rio Grande do Sul, Brazil. Revista brasileira de Zoologia, 24: 1108-1112.

Miers, E. 1877. On a collection of Crustacea, Decapoda and Isopoda, chiefly from South America, with descriptions of new genera and species. Proceedings of the Zoological Society of London, 1877: 653-679, pls. 66-69.

Milne-Edwards, M. 1840. Ordre des isopodes. p. 115-283, pls. 31-33. In: Histoire Naturelle des Crustacés, comprenant l'anatomie, la physiologie et la classficiation de ces animaux. Paris, Librairie Encyclopédique de Roret. Tome Troisième.

Mittermeier, R.A.; Fonseca, G.A.B.; Rylands, A.B. and Brandon, K. 2005. A brief history of biodiversity conservation in Brazil. Conservation Biology, 19: 601-607.

MMA - Ministério do Meio Ambiente, dos Recursos Hídricos e da Amazônia Legal. 1998. Primeiro relatório nacional para a Convenção sobre Diversidade Biológica. Brasília, 283p. Available at: http://www.mma.gov.br/informma/item/7927 [Accessed on 29 November 2017].

Moore, H. 1901. Report on Porto Rican Isopoda. Bulletin of the United States Fish Commission, 20: 163-176, pls. 7-11.

Moreira, C. 1927. Duas espécies novas de crustáceos isópodes terrestres do Brasil. Boletim Biológico, 10: 194-200.

Moreira, C. 1931. Crustacés isopodes terrestres du Brésil. Bulletin de la Societé Zoologique de France, 56: 426-433.

Morrone, J.J. 2014. Biogeographical regionalisation of the Neotropical region. Zootaxa, 3782: 001-110.

Mugnai, R.; Senna, A.R. and Araujo, P.B. 2013. New distribution records of the genus Neotroponiscus Arcangeli, 1936 (Isopoda: Oniscidea: Bathytropidae) from Southeastern and Southern Brazil. Check List, 9: 855-857.

Myers, N.; Mittermeier, R.A.; Mittermeier, C.G.; Fonseca, G.A.B. and Kent, J. 2000. Biodiversity hotspots for conservation priorities. Nature, 403: 853-858. 
Niemeyer, J.C. and da-Silva, E.M. 2006. Efeitos na biomassa de Cubaris murina Brandt (Crustacea: Isopoda) expostos ao solo com glifosato em laboratório. Jornal Brasileiro da Sociedade de Ecotoxicologia, 1: 17-20.

Niemeyer, J.C.; Santos, V.C.; Araujo, P.B. and da-Silva, E.M. 2009. Reproduction of Cubaris murina (Crustacea: Isopoda) under laboratory conditions and its use in ecotoxicity tests. Brazilian Journal of Biology, 69: 137-142.

Niemeyer, J.C.; Santos, V.C.; Rodrigues, J.M.L. and da-Silva, E.M. 2006. Comportamento de Cubaris murina Brandt (Crustacea: Isopoda) em solo com glifosato: testes de fuga em laboratório. Jornal Brasileiro da Sociedade de Ecotoxicologia, 1: 13-16.

Oliveira, G.; Araújo, M.B.; Rangel, T.F.; Alagador, D. and Diniz-Filho, J.A.F. 2012. Conserving the Brazilian semiarid (Caatinga) biome under climate change. Biodiversity and Conservation, 21: 2913-2926.

Patience, A. 1907. On a new British terrestrial isopod. Journal of the Linnean Society London, 30: 42-44, pl. 7.

Pearse, A.S. 1915. An account of the Crustacea collected by the Walker Expedition to Santa Marta, Colombia. Proceedings of the United States National Museum, 49: 531-556, pls. 70-73.

Pearse, A.S. 1917. Isopoda collected by the Bryant Walker Expedition to British Guiana, with notes on Crustacea from other localities. Occasional Papers, Museum of Zoology, University of Michigan, 46: 1-8.

Pearse, A.S. 1921. Crustacea from Lake Valencia, Venezuela. Proceedings of the United States National Museum, 59: 459-462.

Perty, M. 1830-1834. Delectus animalium articulatorum, quae in itinere per Brasiliam annis MDCCCXVII-MDCCCXX jussu et auspiciis Maximiliani Josephi I. Bavariae Regis Augustissimi peracto collgerunt dr. J. B. de Spix et dr. C F. Pb. De Martius. Munique, Fol. Fasc. 3. p.224.

Pinto-da-Rocha, R. 1995. Sinopse da fauna cavernícola do Brasil (1907-1994). Papéis Avulsos de Zoologia, 39: 61-173.

Pires, A.C.; Parizotto, D.R.; Mise, C.M.; Sessegolo, G.C. and Ferreira, R.L. 2015. Chave de identificação interativa de múltiplas entradas para as espécies de invertebrados troglóbios do Brasil. p. 65-74. In: M.A. Rasteiro and W. Sallun-Filho (eds), Anais do $33^{\circ}$ Congresso Brasileiro de Espeleologia. Campinas, SBE. Available at: http://www. cavernas.org.br/anais33cbe/33cbe_065-074.pdf. Accessed on: 5 Jun 2018.

Quadros, A.F. 2010. Os isópodos terrestres são boas ferramentas para monitorar e restaurar áreas impactadas por metais pesados no Brasil? Oecologia Australis, 14: 569-583.

Quadros, A.F. and Araujo, P.B. 2007. Ecological traits of two neotropical oniscideans (Crustacea: Isopoda). Acta Zoologica Sinica, 53: 241-249.

Quadros, A.F. and Araujo, P.B. 2008. An assemblage of terrestrial isopods (Crustacea) in southern Brazil and its contribution to leaf litter processing. Revista brasileira de Zoologia, 25: 58-66.

Quadros, A.F.; Caubet, Y. and Araujo, P.B. 2009. Life history comparison of two terrestrial isopods in relation to habitat specialization. Acta Oecologica, 35: 243-249.

Richardson, A. and Araujo, P.B. 2015. Lifestyles of terrestrial crustaceans. p. 299-336. In: M. Thiel and L. Watling (eds), The natural history of the Crustacea. Lifestyles and feeding biology. Oxford University Press, Oxford, U.K.
Richardson, H. 1905. A monograph on the isopods of North America. Bulletin of the United States National Museum, 54: 583-717.

Roux, P. 1828. Crustacés de la Méditerranée et de son littoral. Marseilles, Imprimerie d'Achard, p. 174, pls. 1-45.

Rull, V. 2011. Neotropical biodiversity: timing and potential drivers. Trends in Ecology \& Evolution, 26: 508-513.

Sars, G. 1899. Isopoda, Tribe 5. Oniscoidea. p. 153-192, pls. 7083. In: An account of the Crustacea of Norway, with short descriptions and figures of all the species. Bergen.

Schmalfuss, H. 1980. A revision of the neotropical genus Ischioscia Verhoeff, with descriptions of four new species (Isopoda, Philosciidae). Studies on Neotropical Fauna and Environment, 15: 125-139.

Schmalfuss, H. 2003. World catalog of terrestrial isopods (Isopoda: Oniscidea). Stuttgarter Beiträge zur Naturkunde, 654: 1-341.

Schmalfuss, H. and Ferrara, F. 1983. Terrestrial isopods from West Africa, Part 3: Family Armadillidae Verhoeff, 1917. Monitore Zoologico Italiano, Nuova Serie, Supplemento, 18: 111-157.

Schmidt, C. 2001. Lista preliminar de los isópodos terrestres (Crustacea, Isopoda, Oniscidea) de Venezuela. Boletín de la Sociedad Venezolana de Espeleología, 35: 1-12.

Schmidt, C. 2002. Contribution to the phylogenetic system of the Crinocheta (Crustacea, Isopoda). Part 1. (Olibrinidae to Scyphaidae s. str.). Mitteilungen aus dem Museum für Naturkunde Berlim, Zoosystematics and Evolution, 78: 275-352.

Schmidt, C. 2003. Contribution to the phylogenetic system of the Crinocheta (Crustacea, Isopoda). Part 2 (Oniscoidea to Armadillidiidae). Mitteilungen aus dem Museum für Naturkunde in Berlin, Zoosystematics and Evolution, 79: 3-179.

Schmidt, C. 2007. Revision of the Neotropical Scleropactidae (Crustacea: Oniscidea). Zoological Journal of the Linnean Society, 151: 1-339.

Schmidt, C. and Leistikow, A. 2004. Catalogue of genera of the terrestrial Isopoda (Crustacea: Isopoda: Oniscidea). Steenstrupia, 28: 1-118.

Schmidt, C. and Leistikow, A. 2005. Review of the genus Androdeloscia Leistikow, with description of four new species (Crustacea: Isopoda: Oniscidea). Entomologische Abhandlungen, 62: 117-163.

Schöbl, J. 1860. Haplophthalmus, eine neue Gattung der Isopoden, mit besonderer Berücksichtigung der Mundtheile untersucht. Zeitschrift für Wissenschaftliche Zoologie, 10: 449-466, pls. 35 and 36.

Schultz, G.A. 1995. Terrestrial isopod crustaceans (Oniscidea) from Paraguay with definition of a new family. Revue Suisse de Zoologie, 102: 387-424.

Schwenck, J. 1927. Papel dos oniscos portadores e disseminadores de ovos nematoides. Boletim de Zoologia e Biologia Marinha, 10: $1-5$.

Sfenthourakis, S. and Taiti, S. 2015. Patterns of taxonomic diversity among terrestrial isopods. ZooKeys, 515: 13-25.

Silva, A.P.B.; Oliveira, I.P.M.R.; Bastos-Pereira, R. and Ferreira, R.L. 2018. Are laboratory studies on behavior of troglobitic species always trustful? A case study with an isopod from Brazil. Behavioural Processes, 153: 55-65. 
Silva, J.L. and Alves, E.S. 2000. Tylos niveus Budde-Lund, 1885 (Crustacea: Isopoda: Oniscidea: Tylidae): redescrição e nova ocorrência para a praia de Taquaras, Santa Catarina, Brasil. Acta Biológica Paranaense, 29: 265-285.

Silva, M.S. and Ferreira, R.L. 2015. Cave invertebrates in Espírito Santo state, Brazil: a primary analysis of endemism, threats and conservation priorities. Subterranean Biology, 16: 79-102.

Silva, M.S. and Ferreira, R.L. 2016. The first two hotspots of subterranean biodiversity in South America. Subterranean Biology, 19: 1-21.

Sokolowicz, C.C.; Araujo, P.B. and Boelter, J.F. 2008. A new species of Benthana (Crustacea: Isopoda: Philosciidae) from southern Brazil. Revista brasileira de Zoologia, 25: 314-318.

Souza, G.D. 1998. The reproductive biology of Ligia exotica (Crustacea, Isopoda, Ligiidae) on the Tramandaí River Jetty, Imbé, Rio Grande do Sul, Brazil. Iheringia, Serie Zoologia, 84: 101-108.

Souza, L.A. and Grangeiro, D.C. 2006. Primeiro registro de crustáceos terrestres (Isopoda, Oniscidea) para a Chapada do Araripe, Ceará, Brasil. Cadernos de Cultura e Ciência, 1:33-39.

Souza, L.A. and Lemos de Castro, A. 1991. The genus Circoniscus Pearse, 1917 in Brazil, with a description of three new species (Isopoda Oniscidea Scleropactidae). Tropical Zoology, 4: 45-64.

Souza, L.A.; Araújo, J.P. and Campos-Filho, I.S. 2011. The genus Trichorhina Budde-Lund in Brazil, with description of seven new species (Isopoda, Oniscidea, Platyarthridae). Iheringia, Série Zoologia, 101: 239-261.

Souza, L.A.; Bezerra, A.V. and Araújo, J.P. 2006. The first troglobitic species of Scleropactidae from Brazil (Crustacea, Isopoda, Oniscidea). Subterranean Biology, 4: 37-43.

Souza, L.A.; Ferreira, R.L. and Senna, A.R. 2015. Amphibious shelter-builder Oniscidea species from the New World with description of a new subfamily, a new genus and a new species from Brazilian Cave (Isopoda, Synocheta, Styloniscidae). PLoS ONE, 10 (5): e0115021.

Souza, L.A.; Senna, A.R. and Kury, A.B. 2010. A new species and first record of Gabunillo Schmalfuss \& Ferrara, 1983 (Isopoda, Oniscidea, Armadillidae) from the Neotropics. Zootaxa, 2677: 1-14.

Souza, L.L.; Azevedo, H.J.C.C.; Vargas, A.B.; Senna, A.R. and Souza, L.A. 2013. First record of Porcellionides pruinosus (Brandt, 1833) (Oniscidea: Porcellionidae) from Trindade Island, off Espírito Santo state coast, Brazil. Boletim do Museu de Biologia Mello Leitão, 32: 71-78.

Souza-Kury, L.A. 1993. Notes on Trichorhina I. Two new species of Northeastern Brazil (Isopoda, Oniscidea, Platyarthridae). Revue Suisse de Zoologie, 100: 197-210.

Souza-Kury, L.A. 1997a. Redescrição e novo registro de Rhyscotus albidemaculatus Budde-Lund, 1908 para o Brasil (Isopoda, Oniscidea, Rhyscotidae). Papéis Avulsos de Zoologia, 40: 105-114.

Souza-Kury, L.A. 1997b. Two new species of Trichorhina from Brazilian Amazonia (Isopoda, Oniscidea, Platyarthridae). Crustaceana, 70: 180-190.

Souza-Kury, L.A. 1998. Malacostraca. Peracarida. Isopoda. Oniscidea. p. 653-674. In: P. Young (ed), Catalogue of Crustacea of Brazil. Rio de Janeiro, Museu Nacional.
Strouhal, H. 1953. Die Cylisticini (Isop. terr.) der Türkei. Istanbul Üniversitesi Fen Fakültesi Mecmuasi, Serı B, 18: 353-372.

Stuxberg, A. 1872. Tvenne nya Oniscider, bescrifne. Öfversigt af Kongliga Vetenskaps-Akademiens Förhandlingar, 29: 3-6.

Stuxberg, A. 1875. Om Nord-Amerikas Oniscider. Öfversigt af kongliga Vetenskaps-Akademiens Förhandlingar, 32: 43-63.

Taiti, S. 2018. Biologia e biogeografia degli isopodi terrestri (Crustacea, Isopoda, Oniscidea). Atti Accademia Nazionale Italiana di Entomologia, Anno LXV, 83-90.

Taiti, S. and Ferrara, F. 1986. Taxonomic revision of the genus Littorophiloscia Hatch, 1947 (Crustacea, Isopoda, Oniscidea) with description of six new species. Journal of Natural History, 20: $1347-1380$.

Taiti, S. and Ferrara, F. 1991. Two new species of terrestrial Isopoda (Crustacea, Oniscidea) from Ascension Island. Journal of Natural History, 25: 901-916.

Taiti, S. and Ferrara, F. 2004. The terrestrial Isopoda (Crustacea: Oniscidea) of the Socotra Archipelago. Fauna of Arabia, 20: 211-325.

Taiti, S.; Montesanto, G. and Vargas, J.A. 2018. Terrestrial Isopoda (Crustacea, Oniscidea) from the coasts of Costa Rica, with descriptions of three new species. Revista de Biologia Tropical, 66, Suppl. 1: S187-S210.

Trajano, E. 2000. Cave faunas in the Atlantic tropical rain forest: composition, ecology and conservation. Biotropica, 32: 882-893.

Trajano, E. and Bichuette, M.E. 2010. Diversity of Brazilian subterranean invertebrates, with a list of troglomorphic taxa. Subterranean Biology, 7: 1-16.

Trajano, E.; Gallão, J.E. and Bichuette, M.E. 2016. Spots of high diversity of troglobites in Brazil: the challenge of measuring subterranean diversity. Biodiversity and Conservation, 25: 1805-1828.

Van Name, W.G. 1920. Isopods collected by the American Museum Congo Expedition. Bulletin of the American Museum of Natural History, 43: 41-108.

Van Name, W.G. 1925. The isopods of Kartabo, Bartica District, British Guiana. Zoologica, 6: 461-503.

Van Name, W.G. 1926. Forest isopods from Barro Colorado Island, Panama Canal Zone. American Museum Novitates, 206: 1-25.

Van Name, W.G. 1936. The American land and freshwater isopod Crustacea. Bulletin of the American Museum of Natural History, 71: 1-535.

Van Name, W.G. 1940. A supplement to the American land and freshwater isopod Crustacea. Bulletin of the American Museum of Natural History, 77: 109-142.

Vandel, A. 1952a. Étude des isopodes terrestres récoltés au Vénézuela par le Dr. G. Marcuzzi. Memorie del Museo Cívico di Storia Naturale di Verona, 3: 59-203.

Vandel, A. 1952b. Les trichoniscides (crustacés - isopodes) de l'hémisphère austral. Mémoires du Muséum National d'Histoire Naturelle, 6: 1-116.

Vandel, A. 1963. Isopodes terrestres recueillis en Amerique du Sud par Claude Delamare Deboutteville. p. 63-100. In: C. D. Deboutteville (ed), Biologie de l'Amerique australe. Paris, Éditions du Centre National de la Recherche Scientifique.

Vandel, A. 1968. Isopodes terrestres. p. 37-168. In: Institut Royal des Sciences de Belgique (ed), Mission Zoologique Belge 
aux Îles Galapagos et en Ecuador (N. et J. Leleup, 1964-65). Brussels, Musee Royale l'Afrique Centrale. Vol. 1.

Verhoeff, K.W. 1908a. Über Isopoden: 15. Aufsatz. Archiv für Biontologie, 2: 335-387, tavv. XXIX-XXXI.

Verhoeff, K.W. 1908b. Über Isopoden. 12. Aufsatz. Neue Oniscoidea aus Mittel- und Südeuropa und zur Klärung einiger bekannter Formen. Archiv für Naturgeschichte, 74: 163-198.

Verhoeff, K.W. 1928. Über einige Isopoden der Zoologischen Staatssammlung in München. Zoologischer Anzeiger, 76: 25-36, 113-123.

Verhoeff, K.W. 1938. Weltstellung der Isopoda terrestria, neue Familien derselben und neues System. Zoologische Jahrbücher, Abteilung für Systematik, Ökologie und Geographie der Tiere, 71:253-264.

Verhoeff, K.W. 1941a. Zur Kenntnis südamerikanischer Oniscoideen. 71. Isopoden-Aufsatz. Zoologischer Anzeiger, 133: $114-126$.

Verhoeff, K.W. 1941b. Über eine neue südamerikanische Gattung der Isopoda terrestria. Zoologischer Anzeiger, 134: 169-173.

Verhoeff, K.W. 1942. Äthiopische Isopoda terrestria der Hamburger Zoologischen Museums. Zoologischer Anzeiger, 140: 1-163.

Verhoeff, K.W. 1949. Über Land-Isopoden aus der Türkei. III. Istanbul Universitesi Fen Fakultesi Mecmuasi, Serı B, 14:21-48.

Vilela, E.F.; Kudo, H. and Loureiro, M. 1971. Oniscoides de Dourados, Estado de Mato Grosso. Seiva, 31: 183-189.

Vilela, E.F.; Reis, L.A. and Loureiro, M.C. 1972. Oniscoides de Viçosa, estado de Minas Gerais (Crustacea Isopoda). Seiva, 32: 11-22.

Warburg, M.; Adis, J.; Rosenberg, M. and Schaller, F. 1997. Ecology and the structure of respiratory organs in a unique amphibious/terrestrial isopod from the Neotropics (Oniscidea: Philosciidae). Studies on Neotropical Fauna and Environment, 32: 52-63.

Wheeler, Q.D.; Raven, P.H. and Wilson, E.O. 2004. Taxonomy: Impediment or Expedient? Science, 303: 285.

Wood, C.T.; Kostanjšeka, R.; Araujo, P.B. and Štrus, J. 2017. Morphology, microhabitat selection and life-history traits of two sympatric woodlice (Crustacea: Isopoda: Oniscidea): a comparative analysis. Zoologischer Anzeiger, 268: 1-10.

Wood, C.T.; Schlindwein, C.C.D.; Soares, G.L.G. and Araujo, P.B. 2012. Feeding rates of Balloniscus sellowii (Crustacea, Isopoda, Oniscidae): the effect of leaf litter decomposition and its relation to the phenolic and flavonoid content. ZooKeys, 176: 231-245.

World Register of Marine Species - WoRMS. 2018. Oniscidea. In: World list of Marine, Freshwater and Terrestrial Crustacea Isopoda. National Museum of Natural History Smithsonian Institution, Washington D.C., USA. Available at: http://www. marinespecies.org/aphia. $p h p ? p=$ taxdetails\&id $=146505$. Accessed 10 Jun 2018.

Zardo, C.M.L. and Loyola e Silva, J. 1988. Primeira ocorrência de Oniscus asellus Linné, 1758 e Porcellionides sexfasciatus (Koch, 1847) no Brasil (Isopoda: Oniscoidea). Ciencia e Cultura, 40: 791-795.

Zardo, C.M.L. 1989. Uma nova espécie de Phalloniscus BuddeLund, 1908 (Crustacea, Oniscoidea) do sul do Brasil. Revista brasileira de Zoologia, 6: 611-615.

Zimmermann, B.L.; Almerão, M.P.; Bouchon, D. and Araujo, P.B. 2012. Detection of Wolbachia (Alphaproteobacteria: Rickettsiales) in three species of terrestrial isopods (Crustacea: Isopoda: Oniscidea) in Brazil. Brazilian Journal of Microbiology, 43: 711-715.

Zimmermann, B.L.; Bouchon, D.; Almerão, M.P. and Araujo, P.B. 2015a. Wolbachia in Neotropical terrestrial isopods. FEMS Microbiology Ecology, 91: fiv025.

Zimmermann, B.L.; Campos-Filho, I.S. and Araujo, P.B. 2018a. Integrative taxonomy reveals a new genus and new species of Philosciidae (Crustacea: Isopoda: Oniscidea) from Neotropical region. Canadian Journal of Zoology, 96: 473-485.

Zimmermann, B.L.; Campos-Filho, I.S.; Cardoso, G.M.; Santos, S.; Aguiar, J.O. and Araujo, P.B. 2018b. Two new species of Atlantoscia Ferrara \& Taiti, 1981 (Isopoda: Oniscidea: Philosciidae) from southern Brazil described in the light of integrative taxonomy. Zootaxa, 4482: 551-565.

Zimmermann, B.L.; Campos-Filho, I.S.; Deprá, M. and Araujo, P.B. 2015b. Taxonomy and molecular phylogeny of the Neotropical genus Atlantoscia (Oniscidea, Philosciidae): DNA barcoding and description of two new species. Zoological Journal of the Linnean Society, 174: 702-717.

Zimmermann, B.L.; Palaoro, A.V.; Bouchon, D.; Almerão, M.P. and Araujo, P.B. 2018c. How coexistence may influence life history: the reproduction strategies of sympatric congeneric terrestrial isopods (Crustacea, Oniscidea). Canadian Journal of Zoology. [e- First Article - doi: 10.1139/cjz-2018-0086] 